\title{
Responsabilidade civil do Banco Mundial face ao desenvolvimento*
}

\section{Civil responsibility of World Bank in face of development}

\author{
[...] é necessário um novo paradigma para o desenvolvimento \\ de capacidades. Primeiro, deve-se abraçar o lema: \\ "procurar globalmente, reinventar localmente."
}

(Carlos Lopes)

Alfa Oumar Diallo

Recebido em: 15/01/2016.

Aprovado em: 28/03/2016.

Graduação em Direito pela PUC/RS (1997), Mestrado (2000) e Doutorado (2006) em Direito pela UFRGS, Pós-doutorado (2014) pela Universidade Católica de Louvain-La-Neuve (Bélgica). Atual Diretor da Faculdade de Direito e Relações Internacional da UFGD/MS. Professor pesquisador nos seguintes temas: África; Auto-determinação dos povos; Cooperação Sul-Sul; Cooperação Internacional para o Desenvolvimento; Relações Internacionais.

\section{Resumo}

O princípio da responsabilidade civil tem por sustentação o consenso de que há um dever geral de não prejudicar ninguém, a que todos nós devemos nos submeter. Mas a clássica concepção do instituto da responsabilidade civil, vinculada essencialmente à esfera subjetiva do agente, no campo da culpabilidade, sofreu profundas mudanças ao longo do tempo. Essa evolução está intrinsecamente associada à crescente complexidade das relações humanas, mormente com o advento da modernidade industrial capitalista.

Assim sendo os bancos foram, paulatinamente, chamados à responsabilização e a análise de crédito passando a incorporar as externalidades, não só do campo econômico-financeiro, mas também em outros campos como os do desenvolvimento, principalmente o Banco Mundial. Se o Banco Mundial financiar atividade ou empreendimento sem a observância das prescrições legais e morais é financiar ilegalidade, assumindo o financiador o papel de responsável ou co-responsável com o fracasso do projeto. Em poucas palavras: se o banco aloca recursos para atividades desenvolvimentistas lícitas, caso haja dano aos direitos humanos durante o financiamento, responde ele integralmente pela reparação do mesmo em situação de agente causador do dano.

Palavras-chave: Responsabilidade civil. Banco Mundial. Desenvolvimento.

\begin{abstract}
The principle of civil liability is to support the consensus that there is a general duty not to harm anyone, we all must submit. But the classic conception of the institute of civil liability, linked mainly to the subjective sphere of the agent in the field of guilt, has undergone profound changes over time. This evolution is intrinsically linked to the increasing complexity of human relationships, especially with the advent of modern industrial capitalism.

Therefore banks were gradually called to accountability and credit analysis going to incorporate externalities, not only the economic and financial field, but also in other fields such as the development, mainly the World Bank. If the World Bank funded activity or project without complying with legal requirements and moral financing is illegal, assuming the role of the financier responsible or co-responsible with the failure of the project. In a few words: if the bank allocates resources for developmental activities lawful if there is damage to human rights during the funding, he responds by fully repair even under causative agent of harm.
\end{abstract}

Keywords: Civil responsibility. World Bank. Development. 


\section{Introdução}

A responsabilidade civil é um instituto altamente dinâmico e flexível, que vive em mudanças constantes, sempre se transformando para atender às necessidades sociais que surgem. Nos últimos tempos, a tendência na sociedade é no sentido de não deixar nenhuma vítima de dano sem reparação. Isso se reflete diretamente no instituto da responsabilidade civil, uma vez que tem proporcionado um fenômeno de expansão dos danos suscetíveis de indenização.

A palavra responsabilidade vem do latim red spondeo, significando a "capacidade de assumir as conseqüências dos atos ou das omissões, que pressupõe a ocorrência de um ilícito"2. Como gênero, portanto, a noção de responsabilidade vincula-se a exame de conduta voluntária violadora de um dever jurídico ${ }^{3}$. O Direito deve ser operacionalizado não somente no sentido de se mostrar como elemento corretivo, de incidência post factum, mas também como instrumento de gestão de risco, atuando preventivamente à efetivação de danos secundários.

Niklas Luhmann ${ }^{4}$ vê o Direito como um sistema autopoético e, utilizando se de um conceito tomado da teoria de Humberto Maturana, explica que a ligação entre Direito (sistema fechado) com o meio ocorre através do acoplamento estrutural comunicativo. Isto quer dizer que a sociedade como um todo é considerada um sistema (meio ou entorno), dentro do qual coexistem subsistemas políticos, econômicos, científicos e, inclusive, jurídicos. O Direito consegue, assim, ter mais dinamismo ao comunicar-se com os demais subsistemas, pois sendo também um sistema submerso no sistema social recebe o que Nihlas Luhmann denomina irradiações do meio.

Para este estudo, o Banco Mundial merece destaque por ser o primeiro e principal Banco de Fomento, ou Banco Multilateral de Desenvolvimento, existente. Segundo Maia ${ }^{5}$ o papel dos bancos de fomento é "mediar entre os principais mercados de capitais e as necessidades de financiamento de projetos do terceiro mundo. Além

2 SÉGUIN, Elida. O direito ambiental: nossa casa planetária. Rio de Janeiro: Forense, 2000. p. 275.

3 VENOSA, Sílvio de Salvo. Direito civil: responsabilidade civil. 3. ed. São Paulo: Atlas, 2003. v. 4.

4 LUHMANN, Niklas. Sociologia do direito. Rio de Janeiro: Tempo Brasileiro, 1983. v. 1.

5 MAIA, M. E. R. Cenários para o sistema financeiro internacional. 1999. Dissertação (Mestrado) - Instituto de Ciência Política e Relações Internacionais, Universidade de Brasília, Brasília, 1999. disso, eles [...] proporcionam assistência técnica e assessoria na área de política econômica”. Assim sendo o financiamento de alguns projetos de cunho desenvolvimentista passam por seu crivo.

O conceito de desenvolvimento, por si só, está intrinsecamente influenciado por diversos interesses e perspectivas, tornando importante conhecer e entender esse conceito, sua evolução e as novas tendências teóricas que tendem a orientar as políticas dos países e das relações entre estes. Inserimos-nos em um contexto de constante necessidade de revisão de ações de desenvolvimento e das próprias relações internacionais, uma vez que "this situation of inadequate development theories and ineffective development policies implies that there is a need for serious rethinking in the field".

Vamos tratar do desenvolvimento como um amplo processo de mudança social, um processo que abrange o setor econômico, social, cultural e político, que objetiva a melhoria e o bem-estar de toda uma população. Aqui adotaremos o conceito de desenvolvimento como um processo, conceito utilizado pela Resolução n.41/128 da Assembléia Geral da Organização das Nações Unidas, onde o desenvolvimento: [...] é um amplo processo econômico, social, cultural e político, que objetiva a melhoria constante do bem-estar de toda uma população e de todos os indivíduos na base de sua participação ativa, livre e consciente no desenvolvimento e na justa distribuição dos benefícios dele restante.

As obras que lidam com a temática da responsabilidade civil do Banco Mundial face ao desenvolvimento são muito escassos; a vasta doutrina trata dos benfeitos da atuação do banco, com a adoção das politicas neoliberais, haja vista os diferentes modelos teóricos associados às relações internacionais.

De outra banda nenhuma organizaçao internacional que pretende agir como sujeito de direito internacional, que entende exercer suas competencias e que pretende ter uma personalidade juridica internacional nao pode seriamente argumentar que ela està imune de cumprir obrigaçoes internacionais, especialmente regras de proteçao dos direitos humanos. Como sujeito de direito internacional, toda organizaçao internacional està submetida ao direito internacional, incluindo à submissao às regras de proteçao aos direitos humanos.

HAQUE, M. Shamsul. Restructuring development theories and policies: a critical study. Albany: State University of New York Press, 1999. p. 374. 
De acordo com Eric Toussaint ${ }^{7}$, o regime da responsabilidade internacional é aplicável ás instituições financeiras internacionais. Estas são responsáveis por violações massivas e sistemáticas do direito internacional como consequência das suas politicas no contexto dos programas de ajustes estruturais. Ao mesmo tempo, o regime de responsabilidade internacional diz respeito à violação das regras do direito penal internacional ou das normas ditas imperativas.

O nosso estudo será dividido em duas partes, sendo que a primeira parte debaterá sobre a responsabilidade civil, subdividida em teorias da responsabilidade civil (Cap. A) e na responsabilidade internacional (Cap. B); a segunda parte tratará do Banco Mundial face ao desenvolvimento, compreendendo a transparência no Banco Mundial (Cap. A) e a responsabilidade civil do Banco Mundial (Cap. B).

Entende-se que a prática do "desenvolvimento" predominante no politica neoliberal do Banco Mundial estaria entremeada pelo discurso político-ideológico próprio da "boa governança", envolvendo transparência, prestação de contas, "boas práticas” e formação de consensos, discurso este que é descolado de uma noção de desenvolvimento fundamentada nas especificidades do território (do "local") e ciente das relações desiguais entre os atores implicados.

\section{Responsabilidade civil}

Uma sociedade com problemas complexos exige pensamentos complexos que incluam uma visão holística em que as argumentações tenham por base o conhecimento científico em suas mais amplas possibilidades. Isto porque somente assim se construirá um novo pensamento livre de posicionamentos sectários que se traduzem por uma blindagem às necessidades da sociedade contemporânea, a qual exige soluções em tempo real, evitando assim que cada vez mais se comprometa o almejado desenvolvimento sustentável.

O princípio da responsabilidade tem por sustentação o consenso de que há um dever geral de não prejudicar ninguém, a que todos nós devemos nos submeter. No Direito Romano, a máxima neminem laedere expressa desde remotos tempos esse princípio, que fez nascer, a

TOUSSAINT, Eric. Banque Mondiale: le coup d'état permanent: l'agenda caché du consensus de Washington. Paris: Syllepse; Genève: Cetim; Liège: CADTM, 2006. partir da prática de atos ilícitos (antijurídicos) com resultados danosos, a obrigação de indenizar ${ }^{8}$.

É necessária a readequação da responsabilidade civil para que o Direito faça frente às demandas por reparação de danos no âmbito da sociedade de risco, com vistas a trazer respostas às consequências nefastas derivadas dos riscos secundários que surgem com o tempo e sem limite de espaço. Assim, o pontapé inicial a ser dado pelo instituto deverá partir do deslocamento de um juízo de certeza para um juízo de probabilidade, pois somente assim demarcar-se-á o caráter preventivo, além do reparatório, que se pretende dar ao sistema de reparação de danos. Isto porque a equação causa e efeito muitas vezes não aparece de forma inconteste.

Mas a clássica concepção do instituto da responsabilidade, vinculada essencialmente à esfera subjetiva do agente, no campo da culpabilidade, sofreu profundas mudanças ao longo do tempo. Essa evolução está intrinsecamente associada à crescente complexidade das relações humanas, mormente com o advento da modernidade industrial capitalista. Para o professor Rui Stoco, "a responsabilidade civil é o instituto de direito civil que teve maior desenvolvimento nos últimos 100 anos"9.

A mudança de perspectiva da responsabilidade civil então, pode-se dizer, migrou, ao longo da história, não apenas desde uma perspectiva privada (voltada para a proteção individual) para uma perspectiva ampliada de garantia da incolumidade dos bens de titularidade difu$\mathrm{sa}^{10}$, como também pendeu no sentido da superação do entendimento de que só pode haver responsabilidade com culpa, isto é, no sentido do afastamento da "concepção subjetiva da culpa"11.

O referido afastamento do elemento subjetivo da culpa só foi possível mediante a adoção de uma nova visão doutrinária, denominada doutrina do risco, que fez progredir o conceito da responsabilidade objetiva, deslo-

$8 \quad$ STOCO, Rui. Tratado de responsabilidade civil: responsabilidade civil e sua interpretação doutrinária e jurisprudencial. 5. ed. São Paulo: Revista dos Tribunais, 2001.

$9 \quad$ STOCO, Rui. Tratado de responsabilidade civil: responsabilidade civil e sua interpretação doutrinária e jurisprudencial. 5. ed. São Paulo: Revista dos Tribunais, 2001. p. 1858.

10 STEIGLEDER, Annelise Monteiro. Considerações sobre o nexo de causalidade na responsabilidade civil por dano ao meio ambiente. Revista de Direito Ambiental, São Paulo, ano 8, n. 32, p. 83-103, out./dez. 2003.

11 STOCO, Rui. Tratado de responsabilidade civil: responsabilidade civil e sua interpretação doutrinária e jurisprudencial. 5. ed. São Paulo: Revista dos Tribunais, 2001. 
cando a questão da responsabilidade extracontratual do critério da responsabilidade fundada na culpa para um ponto de vista exclusivo da reparação das perdas, que já não seria definido pela medida de culpabilidade, mas que deveria surgir do próprio fato causador da lesão a um bem jurídico. Em outras palavras: o problema da reparação dos danos sofridos deve ser proposto a partir da questão de "quem deve reparar os danos" e não da questão de “quem é o responsável”12.

A doutrina da responsabilidade objetiva se contrapunha radicalmente à doutrina subjetivista, sustentadora de uma responsabilidade fundada na culpa. Em que pese as fortes reações dos defensores do subjetivismo, a responsabilidade objetiva agigantou-se nos tempos modernos, sobretudo a partir da segunda metade do século XIX.

O desenvolvimento inexorável da responsabilidade objetiva representa a ruptura das limitações da responsabilidade fundada na culpa que não possibilitava a resolução de "diversos casos que a civilização moderna criava ou agravava"13. Os precursores da doutrina do risco foram os alemães partidários da escola do direito natural. $\mathrm{O}$ que nos diz essa doutrina? Nos diz que o causador de um dano deve ser responsabilizado independentemente da existência de culpa de sua parte ${ }^{14}$, ou seja, imputa-se a responsabilidade objetiva e admite-se o risco como o seu "único fundamento adequado".

E isso por uma questão de ordem moral, porque há que se buscar evitar a chamada "socialização dos riscos" através de um "sistema eficiente de canalização da responsabilidade", numa sociedade de risco como a atual sociedade pós-moderna ${ }^{15}$. Nesses novos tempos, a produção social da riqueza é acompanhada por uma produção social do risco, que expõe como nunca os habitantes do planeta e o meio ambiente a inúmeros riscos e formas de contaminação ${ }^{16}$. Oportuno aqui reproduzir as palavras

12 BARACHO JÚNIOR, José Alfredo de Oliveira. Responsabilidade civil por dano ao meio ambiente. Belo Horizonte: Del Rey, 2000.

13 BARACHO JÚNIOR, José Alfredo de Oliveira. Responsabilidade civil por dano ao meio ambiente. Belo Horizonte: Del Rey, 2000. p. 340.

14 BARACHO JÚNIOR, José Alfredo de Oliveira. Responsabilidade civil por dano ao meio ambiente. Belo Horizonte: Del Rey, 2000. p. 340.

15 STEIGLEDER, Annelise Monteiro. Considerações sobre o nexo de causalidade na responsabilidade civil por dano ao meio ambiente. Revista de Direito Ambiental, São Paulo, ano 8, n. 32, p. 83-103, out./dez. 2003.

16 BECK, 1992 apud DEMAJOROVIC, Jacques. Sociedade de do professor Alvino Lima: "Não é justo, nem racional, nem tampouco eqüitativo e humano, que a vítima, que não colhe os proveitos da atividade criadora de riscos e que para tais riscos não concorreu, suporte os azares da atividade alheia"17.

É certo que o risco é inerente à existência humana. A vida do homem na terra sempre foi marcada por intempéries, doenças, guerras e toda sorte de perigos e ameaças, não sendo possível destacar um período da história ou pré-história em que a humanidade tenha estado livre de riscos e perigos, vivendo em absoluta tranquilidade e harmonia.

Paralelamente ao progresso industrial, pautado na capacidade infinita de gerar conhecimento, ascendem, também, as incertezas em relação ao futuro. Nas observações de Jacques Demajorovic ${ }^{18}$, "parece que a sociedade contemporânea está constantemente avançando sinais vermelhos que desafiam sua capacidade de se ajustar a mudanças cada vez mais rápidas.”

O grande progresso alcançado pela década de 1970 foi o reconhecimento da incerteza em relação ao futuro. Na análise de Edgar Morin ${ }^{19}$, o pensamento tecnoburocrático da época acreditava na previsibilidade do futuro a partir do que se conhecia do passado e se estabilizava no presente.

Robert Kurz ${ }^{20}$ esclarece quando diz que expandiu a angústia em relação ao futuro: nunca existiu na história moderna um consenso tão amplo das elites de todos os países como ocorre hoje; a economia global de mercado e os critérios de concorrência parecem estar além de

risco e responsabilidade socioambiental: perspectivas para a educação corporativa. São Paulo: SENAC, 2003.

17 LIMA, Alvino. Culpa e risco. 2. ed. São Paulo: RT, 1998. p. 195.

18 DEMAJOROVIC, Jacques. Sociedade de risco e responsabilidade socioambiental: perspectivas para a educação corporativa. São Paulo: SENAC, 2003. p. 280.

19 A prospectiva dos anos sessenta afirmava que o passado era arquiconhecido, que o presente era evidentemente conhecido, que os alicerces de nossa sociedade era estável, e que, sobre esses fundamentos assegurados, o futuro forjava no e pelo desenvolvimento de tendências dominantes na economia, da técnica e da ciência. Dessa forma, o pensamento tecnoburocrático acreditava que podia prever o futuro. Ele acreditava, inclusive, em seu otimismo frágil, que o século XXI iria colher os frutos maduros do progresso da humanidade, in MORIN, Edgar. Para onde vai o mundo?. Tradução de Francisco Moras. 2. ed. Petrópolis: Vozes, 2010. pag.11.

20 KURZ, Robert. O futuro é diferente: uma visão da sociedade do século 21. In: OSZLAK, Oscar. Sociedade e Estado superando fronteiras. São Paulo: Fundap, 1998. p.15-34. 
qualquer crítica e formam o sistema de referência geral de toda atividade humana. Mas, por outro lado, talvez nunca tenha existido em toda a história moderna tal insegurança política e econômica, nem uma angústia social em relação ao futuro como os presentes hoje.

O marco para o surgimento da sociedade de risco surgiu através de um clamor social de "socorro" em relação aos abusos cometidos pela sociedade industrial. Segundo Beck ${ }^{21}$, foi a catástrofe de Chernobyl, que provocou um choque antropológico entre as sociedades industrializadas do ocidente no que se refere ao desenvolvimento tecnológico. A catástrofe de Chernobyl chamou a sociedade a refletir a respeito dos riscos que os avanços tecnológicos, no caso o avanço nuclear, poderia causar a toda uma geração.

A modernidade reflexiva demonstra que há certos tipos de riscos que não podem ser considerados como meras externalidades. Riscos que trazem ameaças globais, e em razão disto devem integrar a pauta dos debates públicos e privados. Na reflexão de Edgar $\mathrm{Morin}^{22}$, o avanço da indústria e da tecnologia traz efeitos conflitantes, vantagens e desvantagens que aproveitam e impactam a todos. Não se pode, contudo, conformar-se com as desvantagens, há sempre que se intentar novas alternativas otimizadoras do tempo futuro. ${ }^{23}$.

Os riscos, embora resultantes da decisão humana, surgem de um modo involuntário e independente do pensamento humano, posto que inicialmente são inalcançáveis pelo conhecimento científico. A relevância em abordar esses novos riscos consiste no fato de que eles se formam no seio do próprio processo de modernização e apresentam-se à consciência social nos seus efeitos

${ }^{21}$ BECK, Ulrich. Risk society: towards a new modernity. Londres: Sage, 1992.

22 MORIN, Edgar. Para onde vai o mundo?. Tradução de Francisco Moras. 2. ed. Petrópolis: Vozes, 2010.

23 Desse modo, a poluição, subproduto da industrialização, pode vir a ser seu produto principal. Os benefícios vitais da redução da mortalidade infantil podem desencadear perigos mortais de um 'apagão' demográfico [...] E, tudo isso, novamente, pode sofrer uma reviravolta, contanto que se corrija ou se melhore a técnica, que se multiplique a produção de nutrientes e que se melhore sua partilha. Assim, nenhum fator pode ser considerado como duravelmente estável, constante, isolável na averiguação concreta do vir a ser e, deste fato, nada pode ser predito categoricamente; tudo deve ser conjecturado condicionalmente. ARRETCHE, M. T. S. Emergência e desenvolvimento do welfare state: teorias explicativas. Boletim Informativo e Bibliográfico de Ciências Sociais, Rio de Janeiro, n. 39, p. 1-124, 1995. secundários ${ }^{24}$. Tal expressão é cunhada de Ulrich Beck ${ }^{25}$ (conhecido também como risco do desenvolvimento), muitas vezes catastróficos, em longo prazo e não delimitáveis pelas coordenadas do tempo e do espaço. ${ }^{26}$.

$\mathrm{Na}$ perspectiva da sociedade de risco, percebe-se que o que dantes era resolvido sob a ótica de uma perspectiva fundada apenas nos atores individuais e problemas localizados em um determinado espaço, agora clama por uma análise do problema sob um viés mais comunicacional, isto quer dizer, um exame do direito voltado aos conflitos entre sistemas e suas comunicações (ecológicas, jurídicas, econômica, política) que venha a permitir, inclusive, a observação e a construção de vínculos com o futuro $0^{27}$.

Em síntese, a própria inserção do sentido transindividual e do princípio da dignidade da pessoa humana, vista sob o viés dos atores coletivos, ressalta a importância de uma perspectiva mais sistêmica e comunicacional para lidar com os problemas - tais como os riscos ambientais e o direito das futuras gerações. No cenário que se emerge com a sociedade de risco, não se resolve um problema de maneira isolada ${ }^{28}$. E caberá também ao sistema jurídico

24 É aquele risco que não pode ser cientificamente conhecido no momento do lançamento do produto no mercado, vindo a ser descoberto somente após um período de uso do produto, mostrando-se perigoso à vida, saúde ou segurança do consumidor em virtude do seu conhecimento posterior de efeitos colaterais ou prejudiciais, como ocorre nos casos dos medicamentos. Tal expressão é cunhada de Ulrich Beck. CASTRO, Fabiana Maria Martins Gomes de. Sociedade de Risco e o Futuro do Consumidor. Revista Direito do Consumidor, São Paulo, n. 44, p. 122-140, 2002.

25 BECK, Ulrich. Risk society: towards a new modernity. Londres: Sage, 1992.

26 CASTRO, Fabiana Maria Martins Gomes de. Sociedade de risco e o futuro consumidor. Revista de Direito do Consumidor, São Paulo, v. 11, n. 44, p. 122-140, out./dez. 2002.

27 GIORGI, Raffaele de. Direito, democracia e risco: vínculos com o futuro. Porto Alegre: Safe, 1993.

28 Há, portanto, uma transcendência da dimensão meramente individualista e subjetivamente orientada da dignidade da pessoa humana em direção a um sentido transindividual, policêntrico (haja vista que o centro não está mais na proteção do sujeito, mas dos sujeitos) e comunicacionalmente orientado (isto porque há uma comunicação com as mais diversas áreas quando se estar a falar em solução de problemas advindos do risco do desenvolvimento - área econômica, política, sociológica, jurídica, internacional, ambiental etc). Nesse aspecto, Edgar Morin destaca a multidimensionalidade da realidade social, lembrando que "[...] ela comporta fatores geográficos, econômicos, técnicos políticos, ideológicos [...] Num dado momento, alguns destes fatores podem ser dominantes, mas existe rotatividade no domínio. A dialética não caminha sobre os pés nem sobre a cabeça; ela gira, pois é antes de tudo jogo de 
oferecer proposta de soluções de conflitos adequadas às novas demandas.

As observações tradicionais do Direito em matéria de responsabilidade civil refutam a reparabilidade do dano hipotético ou eventual, exigindo certeza e atualidade do dano. Todavia, essa concepção se mostra demasiadamente restritiva, em virtude da transtemporalidade e da imprevisibilidade que marcam a problemática dos danos secundários (danos advindos do risco do desenvolvimento), especialmente se observada a partir da sociedade de risco.

\subsection{Teorias da responsabilidade civil}

As mutações sociais ocorridas nos últimos séculos, que redundaram em uma sociedade caracterizada pela produção de riscos globais, exigem do Direito, cada vez mais, processos de tomada de decisões em contexto de risco, antecipando-se, inclusive, à concretização dos danos futuros. Délton Winter de Carvalho ${ }^{29}$ discorre que ao contrário do que ocorre na teoria do risco concreto, não se pode exigir a ocorrência de um dano atual como condição sine qua non para imputação objetiva à atividade perigosa ou arriscada quando se está falando em dano ambiental futuro, sob pena de perda de seu sentido preventivo.

\subsubsection{Teoria do risco}

Com a teoria do risco, diz Philippe Le Tourneau, o Juiz não tem de examinar o caráter lícito ou ilícito do ato imputado ao pretenso responsável: as questões de responsabilidade transformam-se em simples problemas objetivos que se reduzem à pesquisa de uma relação de causalidade $^{30}$.

O risco aqui deve ser compreendido como perigo, probabilidade de dano. Logo, aquele que pratica uma atividade perigosa deve assumir o risco de reparar o dano dela decorrente. Vê-se que a doutrina do risco pode ser assim resumida: todo prejuízo deve ser atribuído ao seu autor e reparado por quem o causou, independentemente de ter ou não agido com culpa. Resolve-se o problema

inter-retro-ações, isto é, elo em perpetuo movimento. MORIN, Edgar. Para onde vai o mundo?. Tradução de Francisco Moras. 2. ed. Petrópolis: Vozes, 2010. p. 15.

29 CARVALHO, Délton Winter de. Dano ambiental futuro: a responsabilização civil pelo risco ambiental. Rio de Janeiro: Forense Universitária, 2008.

30 TOURNEAU, Philippe Le, 1976 apud STOCO, Rui. Tratado de responsabilidade civil: responsabilidade civil e sua interpretação doutrinária e jurisprudencial. 5. ed. São Paulo: Revista dos Tribunais, 2001. na relação da causalidade, dispensável qualquer juízo de valor sobre a culpa do responsável, que é aquele que materialmente causou o dano. ${ }^{31}$.

José Cretella Júnior ${ }^{32}$ informa que enquanto a culpa é vinculada ao homem, o risco é ligado ao serviço, à empresa, à coisa, ao aparelhamento. A culpa é pessoal, subjetiva; pressupõe o complexo de operações do espírito humano, de ações e reações [...]. O risco ultrapassa o círculo das possibilidades humanas para se filiar ao engenho, à máquina, à coisa, pelo caráter impessoal e o objetivo que a caracteriza.

A teoria do risco pode ser compreendida como sendo o responsável, em síntese, aquele que, com sua atividade, acaba por gerar risco a direito de outrem. Diversos autores ensinam a respeito das subteorias a respeito do risco, de modo que este trabalho destaca a apresentação realizada por Patrícia Ribeiro Vieira ${ }^{33}$, a qual sintetiza dizendo: pelo risco-proveito, considera-se como responsável aquele que tira vantagem econômica da atividade danosa, com base no princípio de que do lucro nasce o encargo [...]. Segundo o risco-profissional, o dever de indenizar é oriundo da atividade ou profissão exercida pelo lesado. [...]. A reparação, pelo risco excepcional, dá-se em consequência de uma situação de risco, de caráter excepcional, gravosa à coletividade, por exploração de atividade de alta periculosidade [...]. O risco-criado nada mais seria, segundo o professor Caio Mario da Silva Pereira ${ }^{34}$, do que a ampliação do risco-proveito. Basta o exercício de determinada atividade por alguém para que este seja responsável pelos eventos danosos, visto que criou o perigo, sendo isento apenas por ocasião da prova de que tomou todas as medidas prudentes para evitá-lo [...]. O risco-integral é a espécie mais extremada dentre as decorrentes da doutrina reivindicadora do risco, porque impõe o dever de indenizar até mesmo quando se dê o rompimento do nexo causal. Ou seja, o dano é suficiente, o que afasta qualquer tipo de trabalho com excludentes de responsabilidade civil.

Pela modalidade de risco-proveito, responsável será aquele que tira proveito da atividade danosa, com

31 CAVALIERI FILHO, Sergio. Programa de responsabilidade civil. 8. ed. São Paulo: Atlas, 2008.

32 CRETELLA JUNIOR, José. O Estado e a obrigação de indenizar. 2. ed. Rio de Janeiro: Forense, 2002.

33 RIBEIRO, Patrícia. A responsabilidade civil objetiva do direito de danos. Rio de Janeiro: Forense, 2004.

34 PEREIRA, Caio Mário da Silva. Responsabilidade civil. 3. ed. Rio de Janeiro: Forense,1992. p. 24. 
base no seguinte principio ubi emolumentum, ibi onus onde está o ganho, aí reside o encargo. No campo da responsabilidade de risco esta classificação merece reflexão, uma vez que como o desenvolvimento modernizante visa a beneficiar toda a sociedade - ou seja, ela tira proveito daquele -, nada mais justo que toda a sociedade venha a responder pelos danos causados a terceiros pelos riscos do desenvolvimento que ela mesmo teve proveito. A ideia esboçada por esta teoria é a de que o dano deve ser reparado por aquele que retira algum proveito ou vantagem com o fato lesivo. Assim, quem colhe os frutos com a condução de uma atividade perigosa deve experimentar as possíveis consequências prejudiciais que dela poderá decorrer.

Se alguém coloca em funcionamento uma atividade qualquer, responderá pelos eventuais danos que ela porventura venha a acarretar aos indivíduos, independentemente do dano ter sido ocasionado devido a imprudência, negligência, erro de conduta, configurando-se, assim, a responsabilização pela teoria do risco criado. Oportuno esclarecer que nestes casos não importa se o agente causador do dano tenha ou não auferido vantagens com a atividade que criou, já que o que se encara é a atividade em si mesma.

Emmanuel Levy adiciona à questão da responsabilidade pelo risco o critério de confiança. Segundo o entendimento do autor, o sistema considera que toda a sociedade é responsável para com os outros, na medida em que eles têm necessidade de confiar em "nós" para agir e vice-versa. Ademais: na medida em que, para agir, necessitamos de confiar em nós mesmos, não somos responsáveis perante outrem; a relação de que nasce a responsabilidade é uma relação de confiança necessária; a obrigação que ela cria é uma obrigação que gera confiança e, quando essa obrigação não é executada, quando há confiança legítima enganada, há culpa. ${ }^{35}$.

A doutrina objetiva, ao invés de exigir que a responsabilidade civil seja a resultante dos elementos tradicionais (culpa, dano, vínculo de causalidade entre uma e outro) assenta-se na equação binária cujos polos são o dano e a autoria do evento danoso. Sem cogitar da imputabilidade ou investigar a antijuridicidade do fato danoso, o que importa para assegurar o ressarcimento é a verificação se ocorreu o evento e se dele emanou o prejuízo.

35 LEVY, Emmanuel. Responsabilité et contrat. Revue critique de Legislation et Jurisprudence, Paris, v. 28, p. 361-399, trimestrielle, 1998.
Em tal ocorrendo, o autor do fato causador do dano é o responsável ${ }^{36}$.

Em suma, com a adoção da teoria do risco, como pressuposto da responsabilidade civil, mantém-se o comportamento humano (ação ou omissão), o dano e o nexo de causalidade. Todavia, o elemento subjetivo culpa, qualificador desse comportamento, passa a ser irrelevante à medida que o autor da conduta assume o risco de dano que emerge do simples exercício de sua atividade ${ }^{37}$. Depois da análise da teoria do risco, passa-se ao estudo da teoria da precaução.

\subsubsection{Teoria a precaução}

Observando a evolução da teoria da responsabilidade civil, verifica-se que ela vem passando por várias transições. Essa nova realidade jurídica tem buscado fazer emergir no espírito dos intérpretes uma vontade de reformular a teoria da responsabilidade civil contemporânea. Como ponto de partida, pode-se dizer que um dos fundamentos mais procurados têm sido o princípio da precaução, ao lado dos princípios da solidariedade social; e tem como ponto de chegada a observância do princípio da dignidade da pessoa humana, na sua dimensão da reparação integral dos danos.

Segundo Viney e Kourilsky ${ }^{38}$, o princípio da precaução pode ser entendido como:

[...] le principe de précaution ne doit pas être interprété comme une recomendation systématique d'abstention. A l'inverse, et même s'il n'est pas toujours perçu de cette manière par le public, il doit être entendu comme une incitation à l'action. $A u$ dicton, "dans le doute abstiens-toi», le príncipe de précaution substitue l'imperatif: «dans le doute, mets tout en oeuvre pour agir au mieux». ${ }^{39}$

Esse princípio surgiu na década de 70 e assume um papel de destaque no direito ambiental. A Conferência das Nações Unidas sobre o Meio Ambiente Humano,

36 STOCO, Rui. Tratado de responsabilidade civil: responsabilidade civil e sua interpretação doutrinária e jurisprudencial. 5. ed. São Paulo: Revista dos Tribunais, 2001.

37 SAMPAIO, Rogério Marrone de Castro. Direito civil: responsabilidade civil. 3. ed. São Paulo: Atlas, 2003.

38 VINEY, Geneviève; KOURILSKY, Patrick. Le príncipe de précaution. Paris: Odile Jacob, 1999.

39 Tradução "princípio da precaução não deve ser interpretado como uma recomendação sistemática de abstenção". Pelo contrário, e mesmo não sendo ainda percebido desta maneira pelo público, deve ser entendido como uma incitação à ação. Pelo ditado, "na dúvida abstenha-se", o princípio da precaução substitui o imperativo: "na dúvida, faça tudo para agir da melhor maneira possível". VINEY, Geneviève; KOURILSKY, Patrick. Le príncipe de précaution. Paris: Odile Jacob, 1999. p. 12. 
realizada em Estocolmo, em 1972, e a criação do Programa das Nações Unidas para o Meio Ambiente - PNUMA ampliaram o destaque e os debates acerca do princípio da precaução. $\mathrm{Na}$ década de 80 , a ideia de precaução foi incorporada aos textos de diversas declarações e tratados internacionais sobre questões ambientais. Segundo Derani $^{40}$ o princípio da precaução objetiva prevenir já uma suspeição de perigo ou garantir uma suficiente margem de segurança da linha de perigo. Busca o afastamento, no tempo e espaço, do perigo, na busca também da proteção contra o próprio risco e na analise do potencial dano oriundo do conjunto de atividades. Sua atuação se faz sentir, mais apropriadamente, na formação de políticas públicas ambientais, onde a exigência de utilização da melhor tecnologia disponível é necessariamente um corolário.

Passando do princípio da precaução para o princípio da proteção da dignidade da pessoa humana, chega-se à ideia de reparação integral dos danos.

\subsubsection{Principio da dignidade humana}

Por esta concepção, inadmite-se o dano injusto e a perspectiva da vítima assume maior importância que a conduta volitiva do agente. A orientação é de que a vítima de um dano não pode quedar-se irressarcida pelo simples fato de não ser possível identificar, de maneira inconteste, quem seja o real causador do dano. A preocupação com a proliferação do anonimato dos danos reitera a importância acerca da precaução e reparação de dano.

Ignácio Mattozi ${ }^{41}$ assinala que "La nueva realidad social, com su exigencia de defensa de la persona, reclama uma respuesta que tenga por objetivo, no ya castigar los comportamientos negligentes, sino que las víctimas tengam um patrimônio que responderá de los daños acaecidos". Dentro desses novos clamores sociais, percebe-se que os elementos tradicionalmente aceitos na teoria da responsabilidade civil, quais sejam, culpa, dano e nexo de causalidade, precisam ser reformulados.

A figura do ofensor cede lugar à preocupação prioritária para com a pessoa do ofendido, que deverá ser indenizado pelo dano sofrido. Pretende-se viabilizar um direito dos danos que vise prioritariamente a possibilitar a efetiva reparação dos danos. Tal pretensão somente po-

40 DERANI, Cristiane. Direito ambiental econômico. 5. ed. São Paulo: Max Limonad, 2001.

41 MATTOZZI, Ignácio de Cuevillas. La reación de causalidad em la órbita del derecho de daños. Valencia: Tirant lo Blanch, 2000. p. 36. derá ser possivelmente concretizada se estiver pautada nos princípios da solidariedade social - princípio este que será tratado aqui - e na utilização de presunções no sentido de facilitar este ressarcimento, com o propósito de que a dignidade do homem é um valor a ser observado.

Neste sentido é o ensinamento de Luiz Diéz-Pi$\mathrm{cazo}^{42}$, quando diz que a responsabilidade civil estava destinada a moralizar as condutas individuais, deixando, para um "segundo plano", a necessidade de assegurar às vítimas da reparação dos danos sofridos. De fato a visão inicial era esta mesmo, uma preocupação mais genuína em punir o ofensor pelo dano causado, uma espécie de função retributiva. Todavia, com a retomada de valores pautados em princípios, como os da solidariedade social, prevenção e dignidade humana, operou-se uma mudança principiológica, direcionando o foco do direito dos danos à compensação da vítima ante o prejuízo sofrido, enfatizando a perspectiva da justiça distributiva. ${ }^{43}$ Em outras palavras: "o comportamento ofensivo perde relevância ante ao dano sofrido. Esta inversão traz como conseqüência a alteração da perspectiva da responsabilidade civil do ofensor para a ótica da vítima ${ }^{44}$ ".

Passa-se a analisar o dano injusto ${ }^{45}$ sofrido pela vítima, a qual merece reparações, e não mais o ato ilícito. $\mathrm{O}$ objetivo primário é reparar os danos sofridos pela vítima. A punição do ofensor, a análise e reprovabilidade da sua conduta devem ficar a cargo de outra jurisdição funcional, qual seja, a penal.

Maria Celina Bodin ${ }^{46}$ também comunga do mes-

42 DIEZ-PICAZO, Luis. Experiencias jurídicas y teoría del derecho. 3. ed. Barcelona: Ariel, 1999.

43 A justiça distributiva considera a igualdade tendo em vista uma proporção geométrica e se destina a reger as relações entre o Estado e seus súditos, promovendo a repartição das honras e bens segundo os méritos de cada um. AZEVEDO, Plauto Faraco de. Justiça distributiva e aplicação do direito. Porto Alegre: Sérgio Fabris, 1983. p. 58.

44 MULHOLLAND, Caitlin Sampaio. A responsabilidade civil por presunção de causalidade. Rio de Janeiro: GZ, 2009. p. 374.

45 O dano injusto constitui uma cláusula geral, através da qual os aplicadores do direito - mais especificamente os juízes - concretizam as situações de dano ressarcível, analisando não mais a conduta culposa como parâmetro de identificação do ilícito, mas agora a concreta violação do dever de não lesar, criando, assim, a possibilidade da atipicidade dos atos ilícitos e ampliação das hipóteses de reparação. MULHOLLAND, Caitlin Sampaio. A responsabilidade civil por presunção de causalidade. Rio de Janeiro: GZ, 2009. p. 15.

46 MORAES, Maria Celina Bodin de. O principio da solidariedade. In: PEIXINHO, Manoel Messias (Org.). Os princípios da Constituição de 1988. Rio de Janeiro: Lúmen Júris, 2001. p. 167-190. 
mo entendimento quando enfatiza que o Direito Civil somente deve atribuir caráter punitivo à responsabilidade civil em hipóteses excepcionais taxativamente previstas na lei, sob pena de ferir o princípio da legalidade, segundo o qual nullum crimen, nulla poena sine lege. Caitlin Mulholland ${ }^{47}$, por sua vez, informa que: esta virada conceitual, por seu turno, deveu-se principalmente à consolidação de um novo fator de imputação da responsabilidade concretizado por meio da teoria do risco na responsabilidade civil contemporânea e sua crescente aplicação, ao lado da culpa, em igualdade de valor e não mais como hipótese excepcional. A partir do momento em que estas duas fundamentações passam a ser tuteladas de forma equivalente, a função original da responsabilidade civil - sancionar a conduta culposa - abre espaço a um novo argumento, qual seja, a necessidade amparada socialmente - e constitucionalmente - de reparar os danos injustamente sofridos, sejam eles resultados de um agir culposo, seja conseqüência de uma atividade lícita qualquer.

Esta nova leitura da doutrina da responsabilidade civil traz inúmeras consequências em relação aos elementos configuradores da obrigação de indenizar, principalmente no que diga respeito ao elemento denominado nexo causal. Caitlin Mulholland ${ }^{48}$ continua dizendo que “a própria noção de nexo de causalidade, [...], se vê estruturada com vistas a permitir a efetivação do princípio da reparação integral, isto é, a de que todo dano injusto causado a uma pessoa deve ser ressarcido.” Problematizando a relevante questão acerca do nexo de causalidade, continua a autora: [...] presunções do nexo de causalidade, em que a probabilidade substitui o elemento da necessidade de estabelecer a responsabilidade civil. Significa dizer que no ordenamento jurídico brasileiro estão presentes os elementos para que se adotem novos posicionamentos acerca do papel do nexo de causalidade, justificados através da utilização dos princípios da reparação integral e da precaução, e embasados nos princípios da dignidade da pessoa humana (art. $1^{\circ}$, III, da CF) e da solidariedade social (art. $\left.3^{\circ}, \mathrm{I}, \mathrm{da} \mathrm{CF}\right){ }^{49}$ Propõe-se que as presunções

47 MULHOLLAND, Caitlin Sampaio. A responsabilidade civil por presunção de causalidade. Rio de Janeiro: GZ, 2009.

48 MULHOLLAND, Caitlin Sampaio. A responsabilidade civil por presunção de causalidade. Rio de Janeiro: GZ, 2009. p. 374.

49 MULHOLLAND, Caitlin Sampaio. A responsabilidade civil por presunção de causalidade. Rio de Janeiro: GZ, 2009. p. 374 em relação ao dever de indenizar se façam não mais com base em uma certeza do liame causal, mas sim em uma probabilidade quanto à ocorrência do dano.

A finalidade, apresentada sinteticamente, da teoria da responsabilidade civil por presunção de causalidade busca a reparação do dano sofrido e não mais a culpabilização pela conduta danosa. Prima-se pela leitura do caso concreto, que clama por uma reparação civil, sob os auspícios dos princípios da solidariedade social e da dignidade da pessoa humana. Com relação ao primeiro solidariedade social - se evidencia "a obrigação de reparar o dano ainda quando não possa ele ser referido a uma conduta culposa, mas sim, a acontecimento derivado de uma atividade geradora de riscos". Pelo segundo - dignidade da pessoa humana - "na condição de cláusula geral de tutela da pessoa e como justificador das seleções interpretativas que visam a ampliação das possibilidades de reparação de danos." ${ }^{50}$. Mattozi ${ }^{51}$ revela que:

Cuando no se puede probar com exactitud el origen del daño, es el próprio agente quien se encuentra em la necessidad de probar su próprio actuar diligente, es la llamada doctrina de la expansión de la aprecacíon de la prueba en beneficio del más débil. Se trata de um método que vine a modular o integrar el principio consagrado em el art. 1.214 del Código Civil, para que se facilite, em ciertos casos, la prueba da culpa. Por conseguinte, em relación a ciertos hechos de difícil prueba se estabelece um favor probationis, que se traduce em la necessidad que siente el juzgador de dalirse de su estática y fria posición de espectador para coadyuvar em prol de la parte que más dificultades objetivas encuentre em la produccion y estimación de su prueba.

A tendência em admitir uma nova leitura da causa sob um viés da causalidade probabilística promove um incremento, ou melhor, um aumento das hipóteses de ressarcimento dos danos injusto sofridos, pois deixa de lado o problema do anonimato, que era uma constante em tempos pretéritos, para estabelecer como foco a pessoa do ofendido, e como tal merecedor de uma reparação integral. Não há como propor essa nova leitura se não for com base nas diretrizes traçadas pelos princípios da dignidade da pessoa humana e solidariedade social.

Com base no princípio da dignidade da pessoa humana, sabe-se, de antemão, que o mesmo possui duas

50 MULHOLLAND, Caitlin Sampaio. A responsabilidade civil por presunção de causalidade. Rio de Janeiro: GZ, 2009. p. 374.

51 MATTOZZI, Cuevillas Ignácio de. La relación de causalidad en la órbita del derecho de daños. Valencia: Tirant lo Blanch, 2000. p. 156. 
acepções, quais sejam, uma no sentido de garantir que tenha tratamento humano não degradante, no sentido de manter incólume a sua integridade fisiopsíquica; e outra no sentido de que tem o ser humano direito de realizar projetos e propostas através de ações visíveis.

O princípio da dignidade da pessoa humana, empregado na teoria da responsabilidade humana, pode ser destacado da seguinte forma: toda e qualquer situação em que esteja em jogo a discussão entre situação jurídica existencial e situações jurídicas patrimoniais, aquelas sempre deverão prevalecer. Maria Celina Bodin de Moraes $^{52}$ diz que: quando o objeto da tutela é a pessoa humana, a perspectiva deve necessariamente ser outra; torna-se imperativo lógico reconhecer, em razão da especial natureza do interesse protegido, que a pessoa constitui, ao mesmo tempo, o sujeito titular do direito e o ponto de referencia objetivo da relação jurídica.

$\mathrm{O}$ alargamento do nexo de causalidade tem como fundamento primeiro a proteção da dignidade humana, pois somente assim a pessoa do ofendido, vítima do dano injusto, terá a sua reparação como foco primeiro. Ademais, admitida a ampliação dos casos em que se determina a reparação do dano, mais protegida estará a integridade psicofísica da pessoa humana.

Pode-se falar muito mais da influência do princípio da dignidade humana na teoria da responsabilidade civil. Isto porque, além de identificar as hipóteses de dano injusto e os parâmetros para a quantificação deste dano, através da qualificação da pessoa do ofendido, ela pode estabelecer a obrigação de indenizar, priorizando a figura da vítima do dano, nas hipóteses de impossibilidade de prova da causalidade ${ }^{53}$. Ao lado do princípio da dignidade da pessoa humana, caminha o princípio da solidariedade social como vetores da função distributiva que vem sendo buscada pela nova concepção da responsabilidade civil.

Caitlin Mulholland ${ }^{54}$ esclarece o significado da pa-

52 MORAES, Maria Celina Bodin de. O principio da solidariedade. In: PEIXINHO, Manoel Messias (Org.). Os princípios da Constituição de 1988. Rio de Janeiro: Lúmen Júris, 2001. p. 167-190.

53 MORAES, Maria Celina Bodin de. O principio da solidariedade. In: PEIXINHO, Manoel Messias (Org.). Os princípios da Constituição de 1988. Rio de Janeiro: Lúmen Júris, 2001. p. 167-190.

54 MORAES, Maria Celina Bodin de. O principio da solidariedade. In: PEIXINHO, Manoel Messias (Org.). Os princípios da Constituição de 1988. Rio de Janeiro: Lúmen Júris, 2001. p. 167-190. lavra solidariedade: a palavra solidariedade possui diversas acepções, mas todas elas remetem a um mesmo valor significativo, qual sejam, o comprometimento e a reciprocidade existentes entre duas ou mais pessoas pertencentes a uma mesma comunidade. Estes significados apresentam-se simbolicamente, como uma espécie de cola que une todos aqueles que participam de uma determinada sociedade, justificando a sua existência e a sua tutela.

Trazendo as diretrizes do princípio da solidariedade social para a investigação e delimitação do nexo de causalidade, percebe-se que: primeiramente, tal princípio irá nortear o nexo de causalidade com vistas a possibilitar a reparação do dano sofrido por meio da distribuição adequada dos riscos da atividade, impondo àquele que teria as melhores condições de evitar o dano a responsabilidade pelo dano injusto gerado; segundo, a ética advinda do solidarismo social imporia a obrigação de indenizar os danos causados por uma determinada atividade ainda quando não fosse possível à vitima do dano fazer prova irrefutável da existência do liame de causalidade ${ }^{55}$.

Por este entendimento admite-se responsabilizar o réu mesmo que o autor da ação não tenha tido condições de provar, de maneira inconteste, a existência de causalidade, tal como tradicionalmente se lhe impunha. Os fundamentos jurídicos para a nova interpretação do instituto da responsabilidade civil por presunção de causalidade estão pautados em princípios, tais como, precaução, solidariedade social e, como não poderia deixar de ser, pelo princípio da dignidade da pessoa humana.

A aferição da causalidade probabilística, há quem entenda, pode ser realizada por meio de estudos estatísticos em relação aos riscos das atividades desenvolvidas pelos réus. Assim, cada réu que tiver contribuindo para consequência danosa irá responder pelos danos causados de acordo com um cálculo estatístico de probabilidade do dano comparado com a atividade por ele desempenhada.

Depois da análise das diversas teorias da responsabilidade civil, cabe enveredar sobre a responsabilidade internacional.

\subsection{Responsabilidade internacional}

O Direito Internacional Público representa um conjunto de normas que padroniza as relações externas

55 MORAES, Maria Celina Bodin de. O principio da solidariedade. In: PEIXINHO, Manoel Messias (Org.). Os princípios da Constituição de 1988. Rio de Janeiro: Lúmen Júris, 2001. p. 167-190. 
dos atores que compõem a sociedade internacional, atores estes chamados de sujeitos de direito, que compreendem, basicamente, os Estados Nacionais, e, ainda, as Organizações internacionais, como destaca a doutrina.

A noção clássica de responsabilidade implica a idéia de obrigação de reparação de um dano. Nesta concepção conservadora, o prejuízo é o centro gravitacional do instituto da responsabilidade. Não haveria se falar em responsabilidade quando o fato que violasse determinada obrigação não resultasse em prejuízo alheio.

Era esta a noção que vigorava no Direito Internacional até o final do século XX. Com a evolução da solidariedade e cooperação internacional e como resultado da crescente mitigação da idéia de soberania absoluta, a antiga concepção de responsabilidade se tornou inadequada. Não só da violação de normas jus cogens resultará a responsabilidade internacional; advirá ela também da não observância de qualquer obrigação internacional, sendo prescindível a efetiva configuração de um prejuízo.

Neste ponto, vale esclarecer que muitos institutos de responsabilidade já reconhecidos e aplicados com frequência na jurisprudência internacional, bem assim em produções doutrinárias, no tocante aos Estados, também são válidos para as organizações internacionais, por serem estas, à semelhança daqueles, sujeitos de Direito Internacional.

Haverá violação de uma obrigação internacional por uma organização internacional quando um ato desta organização internacional não está em conformidade com o que é exigido da mesma por esta obrigação, independente de sua origem ou caráter. É o que dispõe o parágrafo 1 do art. 8 do projeto da Comissão de Direito Internacional da ONU sobre responsabilidade das organizações internacionais. ${ }^{56}$

Portanto, as obrigações de Direito Internacional podem ser contraídas de forma voluntária, a exemplo de obrigações convencionais resultantes de tratados - que para fins deste trabalho, lembramos, têm como sinônimas as expressões “convenções”, “ajustes”, “pactos”, “acor-

56 COMISSÃO DE DIREITO INTERNACIONAL DA ONU. Relatório 57 (2005). O texto do art. 8, parágrafo 1, em inglês, é o seguinte: "There is a breach of an international obligation by an international organization when an act of that international organization is not in conformity with what is required of it by that obligation, regardless of its origin and character". UNITED UNION. Report of the International Law Commission: fifty-seventh session. New York, 2005. dos" e outros termos que sugerem o mesmo instituto - ou de forma imperativa, em virtude dos princípios gerais de direito, dos costumes, de resoluções do conselho de segurança da ONU ou das obrigações erga omnes que emanam das normas jus cogens - todos reconhecidos como fontes do Direito Internacional. Também pode ocorrer que a violação de determinada obrigação internacional se dê através do descumprimento de regras estabelecidas nos instrumentos constitutivos da organização internacional.

A responsabilidade internacional, pela sua relevância, mereceu atenção especial da Comissão de Direito Internacional (CDI), da Organização das Nações Unidas. A CDI aprovou em 2001 um projeto de Convenção sobre a Responsabilidade do Estado por fato internacionalmente ilícito, iniciado em 1963, sob a presidência do jurista italiano Roberto Ago. A responsabilidade civil internacional dos Estados vem ganhando maior visibilidade, particularmente na grande imprensa, por conta de algumas situações inimaginadas até pouco tempo.

Observa Paulo Henrique Gonçalves Portela na seguinte colocação em seu livro, Direito Internacional Público e Privado: incluindo noções de direito humanos e de direito comunitário, que: efetivamente, a aplicação das normas internacionais é peculiar, em vista de fatores como a complexidade da sociedade internacional, a inexistência de um poder mundial que, a exemplo do Estado, esteja encarregado de impor a observância dos dispositivos de Direito das Gentes, e a circunstância de que os mecanismos internacionais de solução de controvérsias nem sempre têm jurisdição automática sobre os Estados, dependendo destes para existir e de sua anuência para julgá-los. Entretanto, isso não significa que o Direito Internacional não disponha de meios que permitam que os violadores das normas internacionais respondam pelos ilícitos que cometam ${ }^{57}$.

As principais teorias sobre os requisitos exigidos para a existência da responsabilidade são:

1) a teoria da responsabilidade subjetiva ou por culpa: é admitida não apenas quando o ato (ação ou omissão) imputado ao Estado é contrário ao Direito Internacional, como se exige do Estado a culpa;

2) a teoria da responsabilidade objetiva, denomi-

PORTELA, Paulo Henrique Gonçalves. Direito internacional público e privado: incluindo noções de direitos humanos e de direito comunitário. 2. ed. rev. ampl. e atual. São Paulo: JusPodivm, 2010. 
nada sem culpa ou por risco, ainda que o ato imputável ao Estado seja contrário ao Direito Internacional. Os elementos da responsabilidade internacional são:

a) a imputabilidade (elemento subjetivo): o ato (ação ou omissão) deve ser imputado ao Estado como pessoa jurídica de direito público internacional e,

b) a ilicitude (elemento objetivo): o ato (ação ou omissão) deve ser contrário ao Direito Internacional. Isto é, o Estado, autor do ato, deve ter violado uma obrigação internacional e lesionado um Estado, um conjunto de Estados, uma Organização Internacional Governamental ou qualquer pessoa com personalidade jurídica reconhecida pelos foros de solução de litígios internacionais.

Para alguns autores existiria, ainda, um terceiro elemento: o dano, já que consideram que sem este não haveria lesão para reparar e, por conseguinte, tampouco responsabilidade. Esclareça-se, igualmente, que esse dano não significa sempre que seja de ordem material, podendo, não raro, manifestar-se como uma ofensa moral a um Estado, a seus súditos ou patrimônio histórico e cultural.

A responsabilidade civil, conforme anota Varella ${ }^{58}$, “não exige previsão específica em tratado". Além disso, prossegue o autor: o número de situações que podem ensejar a responsabilidade é bem superior à quantidade de práticas consideradas ilícitas pelo direito internacional. Isso, não há listas de atos proibidos, mas apenas normas genéricas, que se referem aos danos. Caso assim fosse, os Estados cujos nacionais praticam atos potencialmente danosos ou com a intenção de lesar outros poderiam simplesmente não se engajar perante os tratados sobre a matéria e escapar de uma eventual indenização, em caso de danos.

Dentre os tratados que regulam a responsabilidade objetiva por atos lícitos estão: a Convenção de Viena sobre Responsabilidade Civil por Danos Nucleares, de 21/05/1963; a Convenção de Bruxelas sobre Responsabilidade Civil por Danos Causados por Poluição por Óleo, de 1969; a Convenção de Bruxelas relativa à Responsabilidade Civil do estabelecimento de um fundo internacional para compensações por danos de poluição por óleo, de 1971; a Convenção de Londres sobre responsabilidade Civil por dano decorrente de poluição por óleo, resultante de exploração de recursos minerais do subsolo Marinho,

58 VARELLA, Marcelo Dias. Direito internacional público. São Paulo: Saraiva, 2009. p. 366. de 1977; e a Convenção sobre a responsabilidade internacional por danos causados por objetos espaciais, de 1972.

A necessidade do instituto da responsabilidade internacional dá-se no fato de que deve haver punição, ou seja, a sanção adequada, para os ilícitos e/ou para os danos advindos de descuidos com o regulamento internacional, não excluindo a obrigação do cumprimento do que foi determinado pelo próprio Estado e pelo Direito Internacional.

No que tange à responsabilidade das organizações internacionais, cujo surgimento no cenário internacional é fenômeno recente em termos históricos, conta com um sistema semelhante ao da responsabilidade dos Estados, o que é decorrência natural da personalidade jurídica internacional conferida àquelas e possibilita incluí-las ao lado destes como sujeitos de Direito Internacional.

Com a natural evolução da institucionalização na ordem internacional, a atuação das organizações internacionais se tornou mais diversificada, mormente com o surgimento das agências e organizações especializadas - por exemplo o Fundo Monetário Internacional (FMI); Organização das Nações Unidas para Educação e Cultura (UNESCO); Organização Mundial do Comércio (OMC); Organização Mundial da Saúde (OMS) - e com a criação de blocos regionais de solidariedade - por exemplo a União Europeia, a Comunidade Econômica dos Estados da África Ocidental (CEDEAO) e o Mercado Comum do Sul (MERCOSUL) - e da mesma forma mais abrangente em termos territoriais.

Destarte, o crescimento do papel operacional das organizações internacionais exigiu, assim como ocorreu em relação aos Estados, a elaboração de um sistema de responsabilidade para estas instituições que pudesse substituir as confusas e esparsas regras costumeiras que orientavam o instituto. Essa demanda vem sendo suprida pela elaboração do projeto da Comissão de Direito Internacional da ONU que dispõe sobre a responsabilidade das organizações internacionais.

As obrigações internacionais podem ser classificadas em obrigações de meio ou de comportamento $e$ obrigações de resultado. Observe-se, desde já, que não se afasta aqui a concepção já demonstrada de que a ocorrência da responsabilidade internacional advirá da simples violação de determinada obrigação imposta pelo Direito Internacional, independentemente da verificação de um prejuízo. Isso não implica em reconhecer que todas as obrigações internacionais seriam, portanto, de simples 
comportamento, mesmo porque, prejuízo e resultado são conceitos distintos. O que se deve ter em mente é, com efeito, a ocorrência efetiva ou não de uma violação à determinada obrigação bem assim se esta impunha ao agente um dever de resultado ou um dever de comportamento que, se não observados, conduzirão à sua responsabilização. É relevante, portanto, perquirir a modalidade da obrigação.

Isso posto, haverá obrigação de meio ou de comportamento quando o sujeito de Direito Internacional estiver vinculado a realizar determinada conduta ou adotar certa postura e não o fizer, isto é, quando o destinatário da obrigação não se comportar de acordo com o que dele era esperado. Por outro lado, se estará diante de uma obrigação de resultado se o sujeito de Direito Internacional gozar de liberdade para a adoção do comportamento que lhe aprouver, ou mesmo de não agir (facultas agendi), apesar de o resultado de seu comportamento, comissivo ou omissivo, ser exigido pelo Direito Internacional.

Para que uma organização seja responsabilizada segundo as normas de Direito Internacional é necessário que a mesma seja reconhecida como sujeito deste mesmo Direito, isto é, que possua personalidade jurídica internacional. Isto implica em dizer que esta entidade deve relacionar-se de forma legítima com outros entes de Direito Internacional, pois foi criada por outros sujeitos dotados de personalidade jurídica internacional distinta da sua e em conformidade com as disposições jus internacionalistas.

\section{Banco Mundial face ao desenvolvimento}

O Banco Mundial surge com a criação do Banco Internacional de Reconstrução e Desenvolvimento (BIRD) durante a Conferência de Bretton Woods, em 1944, ${ }^{59}$ em resposta às necessidades de promoção da reconstrução europeia no pós-guerra e o desenvolvimento das nações

59 Atualmente, o Grupo Banco Mundial é composto de cinco agências, são elas: o Banco Internacional de Reconstrução e Desenvolvimento (BIRD), a Associação Internacional de Desenvolvimento (IDA), a Corporação Financeira Internacional (CFI), a Agência Multilateral de Garantia de Investimentos (AMGI) e o Centro Internacional para Arbitragem de Disputas sobre Investimentos (CIADI). Para realizar seus objetivos, o Grupo utiliza-se dessas agências. Cada agência possui uma atividade específica, mas normalmente o BIRD é considerado o principal representante do Banco Mundial, por ter sido a primeira agência e por administrar praticamente todos os recursos do Grupo. Universitas - Relações Int., Brasília, v. 2, n. 1, p. 269-288, jan./jun. 2004. não desenvolvidas. Em 25 de junho de 1946, começava a funcionar o BIRD e suas primeiras ações tinham o objetivo de reconstruir a Europa. Com o estabelecimento do Plano Marshall ${ }^{60}$, aos poucos esse objetivo foi deixado de lado pelo Banco. Assim, o BIRD concentrou suas atividades para o desenvolvimento econômico, em especial dos países menos desenvolvidos e em desenvolvimento ${ }^{61}$

Assim, em seu desenvolvimento institucional, o Grupo Banco Mundial foi delineando suas estruturas e políticas, de modo a assumir, atualmente, o papel de promoção ao desenvolvimento dos países em desenvolvimento (PED) e por meio de financiamentos a projetos que promovam o combate à pobreza e a utilização sustentável dos recursos das nações. Entre os tipos de projetos que financia, incluem-se projetos nas áreas: de educação, saúde, agricultura, infraestrutura, bem como praticamente todos os setores considerados sensíveis para países em desenvolvimento. Além dos auxílios oferecidos para ajustes no balanço de pagamentos, que criam a confusão entre as obrigações do Banco Mundial (BM) e as do Fundo Monetário Internacional (FMI).

As funções do Banco Internacional de Reconstrução e Desenvolvimento (BIRD), retiradas de seu Estatuto, são as de captar e oferecer empréstimos a PED que sejam considerados bons pagadores ${ }^{62}$. O BIRD capta seus recursos pela venda de títulos nos mercados de capitais a taxas preferenciais, de modo que possa oferecer esses recursos em empréstimos para PED com taxas de juros menores que as de mercado ${ }^{63}$. Graham Bird ${ }^{64}$ comenta que o Banco também atrai recursos do setor privado oferecendo co-fi-

60 Com o final da Segunda Guerra Mundial, muitos países ficaram destruídos. Era necessário muito investimento financeiro para a reconstrução destes países. Neste contexto, foi criado nos Estados Unidos pelo então secretário de Estado George Marshall, um plano econômico cujo principal objetivo era possibilitar a reconstrução dos países capitalistas. A ajuda foi feita, principalmente, através de empréstimos financeiros. O Plano Marshall deve ser entendido dentro do contexto histórico da Guerra Fria, pois foi uma forma de fortalecer o capitalismo e a hegemonia dos Estados Unidos. O Plano foi colocado em operação em 1947. Revista de Estudos Internacionais (REI), v. 2, n. 1, 2011.

61 FOSCHETE, M. Relações econômicas internacionais. 2. ed. São Paulo: Aduaneira, 2001.

62 WORLD BANK. IBRD Articles of Agreement, 2003. Disponível em: <http://siteresources.worldbank.org/BODINT/ Resources/278027-1215526322295/IBRDArticlesOfAgreement_English.pdf >. Acesso em: 14 set. 2013.

63 FOSCHETE, Mozart. Relações econômicas internacionais. 2. ed. São Paulo: Aduaneira, 2001.

64 BIRD, Graham. International financial policy and economic development. 2. ed. London: Macmillan, 1989. 
nanciamento aos países, o que aumenta a disponibilidade de crédito aos PED.

Das outras quatro agências que compõe o Banco Mundial, vale citar ainda, por seu papel no financiamento internacional, a Corporação Financeira Internacional (CFI) que foi criada em 1951 com o objetivo de promover o setor privado nos PED por meio de empréstimo, e a Associação Internacional de Desenvolvimento (IDA), criada em 1960 com o objetivo de conceder empréstimos de longo prazo, com juros muito baixos ou nulos, para projetos em países de baixa renda e com dificuldades em seus balanços de pagamentos ${ }^{65}$, que normalmente se encontram entre os PMD. O BIRD e a IDA juntos formam o que comumente é chamado de Banco Mundial, sendo a maior fonte internacional de recursos para o financiamento do desenvolvimento mundial ${ }^{66}$.

A Declaração do direito ao desenvolvimento, adotada pela Assembleia Geral das Nações Unidas em 1986, através da Resolução 41-128, aparece como uma retomada tardia dos esforços do movimento dos países não alinhados nos anos 60 e 70, quando tinham força e convicção, para impor uma nova ordem econômica internacional (NOEI) mais justa e equitativa. Ela nunca foi colocada em prática, mas conserva, todavia sua pertinência jurídica, politica e moral.

De fato, a Declaração do direito ao desenvolvimento constitui um instrumento internacional de primeira ordem, pois a declaração afirma o direito ao desenvolvimento como um direito humano em todas as suas dimensões e enfatiza os princípios que deverão guiar as relações internacionais, num espirito de igualdade e de respeito mutuo a fim de permitir sua plena realização. Ela coloca o acento sobre os direitos coletivos, o direito dos povos em escolherem seu próprio desenvolvimento e insiste sobre a cooperação internacional entre os Estados, uma cooperação não baseada somente numa pretensa assistência internacional; apesar de que esta seja julgada necessária (Art. 4.2). Neste ponto de vista, ela constitui, globalmente com o conjunto do corpo dos direitos humanos, um instrumento para os povos nas suas lutas contra as políticas neoliberais.

A declaração acorda uma grande importância ao

65 FOSCHETE, Mozart. Relações econômicas internacionais. 2. ed. São Paulo: Aduaneira, 2001.

66 BANCO MUNDIAL. Sobre o Banco Mundial. Disponível em: <http://www.worldbank.org/>. Acesso em: 14 set. 2013. dever dos Estados em cooperarem para assegurar o desenvolvimento e eliminar os obstáculos do desenvolvimento (art. 3.3), assim como criar condições nacionais e internacionais favoráveis à realização do direito ao desenvolvimento (Art. 3.1).

\subsection{Transparência no Banco Mundial}

Há três décadas, o Conselho de Diretores Executivos do Banco Mundial deu um passo arrojado para aumentar a transparência e responsabilidade das operações do Banco, ao estabelecer um mecanismo independente de inspeção - conhecido como Painel de Inspeção. O Painel é uma entidade de três membros criado em 1993 a fim de proporcionar um fórum independente a cidadãos que acreditam que eles ou seus interesses foram ou podem vir a ser diretamente prejudicados por um projeto financiado pelo Banco Mundial. O Painel é a primeira entidade dessa espécie, que dá voz a cidadãos no contexto do desenvolvimento internacional.

A criação do Painel de Inspeção proporcionou, pela primeira vez, um veículo para cidadãos, e especialmente, pessoas pobres, acessar diretamente a mais alta instância administrativa do Banco Mundial - o Conselho de Diretores Executivos - e buscar reparação para o que pode ser entendido como consequências operacionais prejudiciais do Banco Mundial. O processo para endereçar reivindicações - que foi desenvolvido e ainda está sendo aprimorado pelo Painel - deu poderes e voz a população que pudesse ter sido adversamente afetada por projetos financiados pelo Banco. O Painel evoluiu como um mecanismo independente, completo e profundo, para o endereçamento do cumprimento com as políticas do Banco, capacitando a instituição a escutar queixas trazidas pelas pessoas, considerar as avaliações do Painel dessas reivindicações, e adotar melhores políticas e procedimentos operacionais para programar sua missão de redução de pobreza do Banco com maior êxito.

Desde que o Painel iniciou suas operações em setembro de 1994, vinte e sete (27) pedidos formais de inspeção já foram recebidos. Os textos destes pedidos estão disponíveis ao público no site do Painel na internet: <http://www.inspectionpanel.org>. Ao avançarmos no século 21, responsabilidade e transparência nas operações do Banco são ainda mais importantes que há 10 anos, e o Banco segue na linha de frente dos esforços para assegurar que neste contexto, políticas e procedimentos de desenvolvimento verdadeiramente beneficiem as pes- 
soas pobres. Mais especificamente, através do Painel de Inspeção, o Banco procura assegurar que suas políticas e procedimentos operacionais, que têm a intenção de proteger os interesses daqueles afetados por seus projetos, sejam cumpridos no desenho, preparação, e implementação do projeto. Apesar da boa intenção do Banco, ainda há projetos financiados por ele e que causam prejuízos enormes às populações. A criação do Painel inspirou outras instituições financeiras internacionais (IFI) a seguirem o exemplo e darem valor a um mecanismo independente de responsabilidade sobre o qual modelaram seus próprios mecanismos de responsabilidade. De fato, a maioria das IFI considera o mecanismo do Banco Mundial como o padrão de excelência a seguir em seus próprios esforços de aprimorar os conceitos de transparência e responsabilidade.

Ao analisar as transformações do Banco Mundial como organismo de desenvolvimento, João Márcio Pereira ${ }^{67}$ observa as mudanças no perfil da organização durante as últimas décadas. Para ele, o Banco soube articular a relação entre dinheiro, prescrições políticas e conhecimento econômico para impulsionar sua influência em todo o mundo, principalmente nos países em desenvolvimento. Isso possibilitou a institucionalização de sua pauta de políticas em âmbito nacional, seja por meio da coerção, com a manipulação dos empréstimos e a articulação com outras agências, seja por meios persuasivos, de forma dialogada com os governos e o oferecimento de assistência técnica. Tal pensamento coaduna com as análises neogramscianas ${ }^{68}$ do papel dos organismos in-

67 PEREIRA, João Márcio Mendes. O Banco Mundial como ator político, intelectual e financeiro. Rio de Janeiro: Civilização Brasileira, 2010.

68 Vários são os rótulos dados às várias perspectivas que buscam entender a economia política global partindo de Gramsci. "Marxismo Aberto", "Historicismo Coxiano", "Neogramscismo", "Materialismo Histórico Transnacional", "Transnacionalismo Gramsciano", "Escola Italiana das Relações Internacionais" e "Escola Neogramsciana" são exemplos. O ponto comum de tais perspectivas é a aplicação do método materialista histórico ao estudo das relações sociais transnacionais [2], o que compreenderia: 1) uma filosofia materialista da história que levaria ao primado ontológico das relações sociais de produção; 2) uma rejeição da separação entre sujeito e objeto e a adoção de um entendimento dialético da realidade como uma totalidade dinâmica e como uma unidade de opostos; 3) o método de abstração de Marx, conforme explicitado nos Grundrisse. RAMOS, Leonardo César Souza. Resenha: GILL, Stephen. Power and resistance in the new world order. New York: Palgrave Macmillan, 2003. Contexto internacional, v. 26, n. 1, p. 219-226, 2004. ternacionais na estruturação do sistema mundial pelo consenso e pela força ${ }^{69}$. Conforme o estudo de Pereira ${ }^{70}$, com essas ações o Banco Mundial alcançou uma posição privilegiada em relação a outras organizações internacionais, na inserção de agendas políticas e institucionais nos países em desenvolvimento, sendo fundamental para a reformulação do papel do Estado.

A partir de 1995 até os dias atuais, o Banco transformou-se em articulador das políticas dos países desenvolvidos, tanto na manutenção das instituições que interessavam quanto na reformulação do programa neoliberal, diante das crises dos últimos anos, mantendo um papel hegemônico de formulador de políticas.

Ao final da era Wolfensohn [1995-2005] $]^{71}$, o Banco ostentava uma posição sem rival em matéria de influência intelectual. Suas publicações eram referências obrigatórias em cursos de Economia no mundo inteiro, sendo citados mais do que as médias das revistas de economia. Para a elaboração de uma gama variadíssima de pesquisas acadêmicas, a dependência dos indicadores socioeconômicos produzidos pelo Banco, em regime de quase monopólio, era incontornável. O Relatório sobre o desenvolvimento Mundial (RDM), editado anualmente desde 1978, era de longe a publicação do gênero mais citada no mundo. Servia para sumarizar o "estado das artes" em várias áreas relacionadas a políticas de desenvolvimento e estabelecer um roteiro autorizado de discussão, ancorando-se e dando visibilidade à literatura afinada com o paradigma neoliberal produzido dentro e fora do Banco ${ }^{72}$.

A trajetória acima indica que o papel do Banco Mundial vai muito além de mero agente financiador, pois alcançou um protagonismo na produção intelectual e no direcionamento político do mundo contemporâneo. Constituiu-se em uma organização fundamental no processo de cooperação Norte-Sul, sendo uma das principais fontes de recursos para muitos Estados programarem políticas nacionais em diversas áreas. Seu protagonismo

COX, Robert W.; SINCLAIR, Timothy J. Approaches to world order. Cambridge: Cambridge University Press, 1996. (Cambridge Studies in International Relations).

70 PEREIRA, João Márcio Mendes. O Banco Mundial como ator político, intelectual e financeiro. Rio de Janeiro: Civilização Brasileira, 2010.

71 A “autorreforma” do Banco Mundial durante a gestão Wolfensohn (1995- 2005).

72 PEREIRA, João Márcio Mendes. O Banco Mundial como ator político, intelectual e financeiro. Rio de Janeiro: Civilização Brasileira, 2010. 
e visibilidade levam a instituição a ser muito analisada e receber diversas críticas por sua atuação. Brandão ${ }^{73}$, por exemplo, destaca que a hegemonia do pensamento único levou à exacerbação das ações localistas de desenvolvimento, sendo o Banco o principal disseminador dessas práticas. Para Brandão, o incentivo às políticas de desenvolvimento local do Banco é tão intenso que penetra todos os campos de conhecimento, tornando-se uma política de aceitação universal, sem uma reflexão aprofundada dos impactos e resultados desses programas. Outra vertente crítica é formulada por Ribeiro Filho ${ }^{74}$ quando ressalta o efeito do crescimento dos programas direcionados ao desenvolvimento institucional, que está presente na maioria dos projetos financiados como mecanismo de garantia, disseminação e controle de propostas hegemônicas e pacotes de projetos com viés nitidamente neoliberal.

Na nossa ótica, a declaração para o desenvolvimento pode constituir para os movimentos sociais uma referencia jurídica e moral importante para suas reivindicações. Eles poderão também relembrar aos seus governos seus compromissos quando da assinatura da declaração, inclusive quando assinam cartas de intensões que o FMI lhes impõe, ratificam acordos da OMC ou dão autorizações de exploração e de investimento para sociedades transnacionais. $\mathrm{O}$ artigo 10 da declaração dispõe que, medidas devem ser tomadas para assegurar o exercício integral e um reforço progressivo do direito ao desenvolvimento, incluindo a formulação, a adoção e a concretização de medidas politicas, legislativas e outras nos planos nacional e internacional.

No contexto da globalização e na implantação de politicas neoliberais quase no mundo inteiro, a tarefa fica difícil. De fato, as instituições financeiras internacionais (FMI, Banco Mundial) impõem aos Estados politicas neoliberais através dos programas de ajustes estruturais. A OMC, no seu turno, apesar do principio de igualdade entre os Estados, suas regras dão mais força aos Estados mais fortes. Pelas suas politicas, estas instituições visam

73 BRANDÃO, Carlos. Território e desenvolvimento: as múltiplas escalas entre o local e o global. Campinas: Unicamp, 2007.

74 RIBEIRO FILHO, Geraldo Browne. O Banco Mundial e as cidades: construindo instituições na periferia: o caso do PRODUR, Bahia. 2006. 243 f. Tese (Doutorado) - Programa de Pós-Graduação em Planejamento Urbano e Regional, Universidade Federal do Rio de Janeiro, Rio de Janeiro, 2006. a hegemonia do mercado em detrimento da democracia e do desenvolvimento. Neste contexto, precisa sublinhar que, colocados sob pressão, os Estados tendem a abrirem mão do seu papel e de suas responsabilidades que consistem, entre outras, cuidar da equidade e da justiça na repartição da riqueza. Eles se colocam, infelizmente, num papel de lobby e de repressão, em proveito das sociedades transnacionais. O espaço liberado assim pelos Estados é ocupado por diversos organismos, nacionais ou internacionais, que a princípio não podem substituir o Estado, para responder às necessidades das populações cujo numero de pobres e de oprimidos não para de crescer.

$\mathrm{O}$ direito à autodeterminação e à soberania dos povos sobre seus recursos e seu futuro estão no centro do direito ao desenvolvimento. É por isso, os Estados, principais atores da realização do direito ao desenvolvimento, não podem ceder seus atributos às mãos invisíveis do mercado. Entre as medidas urgentes que se impõem para sair deste impasse, podemos citar a democratização e a transparência das tomadas de decisões no seio das instituições supramencionadas, lhes reformando no fundo ou lhes trocando por outras, e a submissão das sociedades transnacionais num enquadramento jurídico no plano nacional e internacional. ${ }^{75}$

Parece que esquecemos que a declaração do direito ao desenvolvimento é a síntese de todos os direitos humanos, assim como os direitos civis e políticos que os direitos econômicos, sociais e culturais. E esquecemos também que existe um Pacto internacional relativo aos direitos econômicos, sociais e culturais que entrou em vigor há mais de 30 anos, e que ele tem um caráter obrigatório para os Estados. Este pacto, como aquele sobre os direitos civis e políticos, a Declaração Universal dos direitos do homem, constituem a base do direito internacional em matéria de direitos do homem. Neste caso, a declaração sobre o direito ao desenvolvimento deve ser considerada ao mesmo titulo que a Declaração Universal dos direitos do homem.

Uma visão baseada nos direitos humanos inspira-se das normas internacionais na matéria, as quais os países aderiram voluntariamente. As agencias de desenvolvimento das Nações Unidas e outros sujeitos de direito internacional estão juridicamente obrigados a

75 Ver a este respeito a brochura intitulada Sociétés transnationales et droits humains, novembre 2005, collection du Programme Droits Humains du Centre Europe - Tiers Monde (CETIM). 
respeitar e trabalhar nos limites fixados pelas obrigações do direito internacional aos quais os Estados se subscreveram voluntariamente, notadamente as normas de direitos humanos.

\subsection{Responsabilidade civil do Banco Mundial}

Emprestar dinheiro é tarefa dos bancos, isto é uma de suas atividades. O financiamento de projetos envolve riscos e os bancos, através de seus analistas de crédito, têm muito se preocupado com o retorno de seu capital na hora de sua concessão. Há um tempo atrás predominava uma visão inteiramente capitalista, voltada exclusivamente para os interesses dos próprios agentes financeiros. Paulatinamente os bancos foram chamados à responsabilização e a análise de crédito passou a incorporar as externalidades, não só do campo econômico-financeiro, mas também de outros campos como o das relações de consumo, do meio ambiente, enfim dos direitos humanos.

Santos $^{76}$, ao discorrer sobre a responsabilidade na atividade bancária das instituições financeiras, nos dá a oportunidade de utilizar os seus argumentos para fazer-nos melhor perceber a evolução da responsabilidade dos agentes em suas atividades de risco, num mundo com interações sociais cada vez mais complexas. O autor aponta para o aumento da responsabilidade civil dos bancos na medida de sua evolução tecnológica. Por intermédio desta presunção de culpa, a responsabilidade encontra-se predominantemente com o agente passivo causador do fato danoso e permanece com ele até a real comprovação fática de que não agiu com culpa. Por fim, na atual fase, caracterizada pela adoção da teoria objetiva, onde a culpa é totalmente abstraída e, em decorrência, a sociedade usuária dos serviços bancários, desimpedida do obstáculo do ônus da prova. Assim veio a teoria do risco, em bom momento, socorrer todos inclusos na sociedade desprotegida, em especial a quem não tem o contrato como elemento probatório essencial de imputação da culpa.

$\mathrm{Na}$ Conferência sobre Meio Ambiente e Desenvolvimento, ECO 92, como ficou conhecida, acatou-se como meta a ser buscada, o modelo do desenvolvimento sustentável adotado na Declaração do Rio (Princípio 4: "Para se alcançar o desenvolvimento sustentável, a pro-

76 SANTOS, Mauro Henrique Pereira dos. A responsabilidade civil objetiva na atividade bancária das instituições financeira. Âmbito Jurídico, Rio Grande, v. 8, n. 20, fev. 2005. Disponível em: <http://www.ambito-juridico.com. $\mathrm{br} /$ site/?n_link=revista_artigos_leitura\&artigo_id=831>. Acesso em: 11 out. 2013. teção do meio ambiente deve constituir parte integrante do processo de desenvolvimento e não pode ser considerada isoladamente em relação a ele") e na Agenda 21, por desenvolvimento sustentável, a Comissão Mundial sobre Meio Ambiente e Desenvolvimento entende como "aquele que atende às necessidades do presente sem comprometer a possibilidade das gerações futuras atenderem as suas próprias necessidades"77.

João Márcio Pereira ${ }^{78}$, ao realizar um amplo estudo sobre a ação do Banco Mundial, destaca que a instituição jamais foi um banco tradicional, pois atua como agente financiador, político e intelectual ao definir agendas das políticas nacionais, ao liberar recursos em programas de diversas finalidades e em definir metodologias e prioridades. Em Elza Kraychete ${ }^{79}$ também se observam reflexões críticas sobre o papel ideológico e hegemônico do Banco na criação e disseminação do discurso liberal, que condiciona uma agenda de políticas públicas em todo o mundo.

Em 1952, houve uma reorganização estrutural no modo de negociação e definição dos empréstimos que visou evitar conflitos entre os funcionários do Banco sobre a responsabilidade de aprovar projetos. Essa reforma criou novos setores organizacionais mais específicos em suas funções e obrigações, tornando mais eficiente o processo de financiamento dos países.

Em Salvatore ${ }^{80}$, tem-se que o Sistema Financeiro Internacional (SFI) representa os costumes, instrumentos e organizações que visam regulamentar as relações entre Estados, mercados e moedas. A definição das estratégias de investimento e financiamento é feita pelos atores desse sistema no qual se incluem os Estados, a iniciativa privada, os bancos e as instituições financeiras internacionais (IFI).

Tratando-se do Banco Mundial, ele oferece diversos serviços aos seus associados pelos quais visa realizar sua missão de erradicar a pobreza no mundo. Entre esses

MILLARÉ, Édis. Direito do ambiente: doutrina, prática, jurisprudência, glossário. 2. ed. São Paulo: RT, 2001. p. 783.

78 PEREIRA, João Márcio Mendes. O Banco Mundial como ator político, intelectual e financeiro. Rio de Janeiro: Civilização Brasileira, 2010.

79 KRAYCHETE, Elsa Sousa. O Banco Mundial e o desenvolvimento das microfinanças em países da periferia capitalista, 2005. 222 f. Tese (Doutorado) - Programa de Pós-Graduação em Administração, Universidade Federal da Bahia, Salvador, 2005.

80 SALVATORE, Dominick. Economia internacional. 6. ed. Rio de Janeiro: LTC, 2000. 
serviços encontram-se os estudos sobre diversos temas de desenvolvimento, consultorias para governos, oferecendo know how para a adequação de políticas que visem esse desenvolvimento, além dos serviços financeiros. Não há dúvidas quanto à importância das análises e estudos realizados pelo staff do Banco. Nesse sentido, Mikesell ${ }^{81}$ comenta que desde seus primeiros anos o Banco buscou não ser apenas uma agência voltada para financiamento de projetos, tentando oferecer outros serviços que promovessem o desenvolvimento econômico.

Por exemplo, os estudos realizados pelo banco permitem delinear suas estratégias para atingir seus objetivos desenvolvimentistas. Já seus relatórios permitem averiguar o andamento dos trabalhos e projetos realizados e as pesquisas estatísticas servem de base para a melhor alocação dos recursos mundiais. Tudo isso também serve de fonte para outros trabalhos, como esta pesquisa. Sem falar que cria o know how necessário para o estabelecimento das consultorias junto aos governos interessados, muito importantes para os PMD que frequentemente estão com suas instituições estatais em condições precárias e necessitam desse auxílio institucional. ${ }^{82}$

As operações não financeiras são também muito úteis ao banco na definição de suas operações financeiras. Apesar das operações financeiras do banco ter uma estrutura própria, as estratégias para a definição de empréstimos e financiamentos vêm das operações não financeiras. Para saber se tais estratégias são realmente aplicadas, o melhor meio é verificar como foram utilizados os produtos e serviços financeiros do banco.

Com esse fim, é importante saber quais são os serviços e produtos financeiros do banco, como eles são utilizados, por quem e para o quê. Os empréstimos realizados pelo banco são definidos segundo dois itens, os instrumentos de financiamento e os produtos financeiros. Os instrumentos de financiamento (ou empréstimos) são os definidores do formato do empréstimo. De acordo com o instrumento utilizado define-se como será o empréstimo e para que fins. São dois os tipos básicos de instrumentos, os empréstimos de investimento e os empréstimos de ajuste. Os empréstimos passam por diversas

$81 \quad$ STANS, Maurice H. Publications of the National Bureau of Standards, 1966-1967. United States Department of Commerce.

82 Mikesell também faz referências aos estudos econômicos do Banco, apesar de comentar que muitos economistas criticarem tais estudos por serem superficiais em suas recomendações. fases antes de se tornarem efetivos, sendo negociados, entre o tomador do empréstimo e o banco, os objetivos do empréstimo, sua agenda de desembolso e pagamentos, e a viabilidade do projeto, etc. Por fim, todos os empréstimos aprovados são regidos pelas políticas operacionais do Banco Mundial ${ }^{83}$.

Os empréstimos de investimento são de longo prazo (de 5 a 10 anos) oferecido pelo Banco a PED, que se mostrem "bons devedores", para projetos que visem o desenvolvimento social e econômico. Os recursos desses empréstimos podem ser desembolsados conforme as necessidades do projeto que são direcionados, ou conforme tenha sido acordado no contrato de empréstimo. Entre os principais instrumentos utilizados por esse tipo de empréstimo, encontram-se: a) Specific Investment Loan (SILs); b) Adaptable Program Loan (APLs); c) Learning and Innovation Loan (LILs); e d) Technical Assistance Loan (TALs). ${ }^{84}$

Os empréstimos de ajuste não são voltados para projetos, a não ser quando utilizados em conjunto com os empréstimos de investimento, por serem oferecidos pelo banco para um desembolso rápido (curto-prazo) por países que necessitem auxílio financeiro externo para reformas estruturais em sua economia como um todo. Os saques são feitos em estágios e segundo termos definidos pelo banco, sendo normal a supervisão do FMI nesse processo de empréstimos para ajustes estruturais. Entre os instrumentos desse tipo de empréstimo têm-se os Structural e Sector Adjustment Loans, os Programmatic e Special Adjustment Loan, o Rehabilitation Loan e o Debt Reduction Loan ${ }^{85}$.

Quanto aos produtos financeiros do banco, esses dizem respeito aos termos em que serão realizados os empréstimos e financiamentos. Apenas o BIRD se utiliza desses produtos, visto que a IDA não cobra juros ou outros encargos dos empréstimos que oferece. O BIRD dispõe de, basicamente, dois tipos de produtos financeiros, os empréstimos de margem fixa (EMF) e os empréstimos de margem variável (EMV). Esses dois produtos são ofe-

83 WORLD BANK. World Bank lending instruments: resources for development impact (operations policy and strategy). Washington: World Bank, 2001.

84 WORLD BANK. World Bank lending instruments: resources for development impact (operations policy and strategy). Washington: World Bank, 2001.

85 WORLD BANK. World Bank lending instruments: resources for development impact (operations policy and strategy). Washington: World Bank, 2001. 
recidos nas principais moedas conversíveis e suas taxas de juros são calculadas de acordo com a LIBOR ${ }^{86}$ semestral, com a diferença de que os EMF possuem uma parte de suas taxas de juros que permanece fixa por toda a duração do empréstimo, a não ser que sejam renegociadas. Outras diferenças entre esses dois produtos incluem o fato dos EMF permitirem maior controle das taxas de juros, permitindo a negociação de correções nessas, facilitando o pagamento aos tomadores. Em compensação, os EMF incluem encargos maiores que o EMV, para compensar os riscos do mesmo ${ }^{87}$.

Vale citar ainda algumas linhas de crédito especiais fornecidas pelo Banco Mundial. Essas linhas referem-se a fundos ou auxílios que não têm origem em recursos exclusivos do grupo. Por exemplo, o Grupo Banco Mundial oferece garantias aos investidores privados que resolverem oferecer empréstimos a PED. Mas a maior parte das linhas de créditos se origina de outras instituições internacionais, principalmente fundos, cuja responsabilidade de programar seus objetivos seja do Banco Mundial ${ }^{88}$. Nesse caso, encontram-se os empréstimos oferecidos pelo Global Environmental Facility (GEF) estabelecido em 1991 e que já está envolvido em mais de 1200 projetos ambientais, inclusive no setor energético.

Com todas essas linhas de créditos, em 2002 o BIRD chegou a liberar US\$ 11,5 bilhões em novos empréstimos. Castro ${ }^{89}$ explica que o Banco consegue seus recursos por meio da subscrição de capital por parte de seus membros. Roberts ${ }^{90}$ comenta ainda que mais recursos são captados nos mercados financeiros por meio da emissão de títulos. Desse modo, o Banco Mundial consegue tamanhos recursos para por em prática todas as suas atividades e financiar o desenvolvimento econômico e social no planeta.

Segundo Roberts ${ }^{91}$ as instituições assumiram no-

LIBOR: taxa de oferta interbancária de Londres.

87 WORLD BANK. Information Statement International Bank for Reconstruction and Development. 2012. Disponível em: $<$ http://treasury.worldbank.org/cmd/pdf/InformationStatement.pdf $>$. Acesso em: 14 mar. 2013.

88 WORLD BANK. Information Statement International Bank for Reconstruction and Development. 2012. Disponível em: $<$ http://treasury.worldbank.org/cmd/pdf/InformationStatement.pdf $>$. Acesso em: 14 mar. 2013.

89 CASTRO, Robinson Gonçalves de. Relações econômicas internacionais. 2. ed. Brasília: Vestcon, 2000.

90 ROBERTS, Richard. Por dentro das finanças internacionais: guia prático dos mercados e instituições financeiras. Rio de Janeiro: Jorge Zahar, 2000.

91 ROBERTS, Richard. Por dentro das finanças internacionais: vas responsabilidades e tornaram-se "as principais instituições públicas que operam as finanças internacionais", servindo de eixo para as relações entre os mercados financeiros internacionais. Apesar disso, ele comenta que elas estão diminuindo suas atividades em vista do aumento das atividades dos mercados financeiros internacionais que, na verdade, só estão crescendo graças à ação bem sucedida das IFI ao longo dos anos.

Mas nos anos 80, a eclosão da crise de endividamento abriu espaço para uma ampla transformação do papel até então desempenhado pelo Banco Mundial e pelo conjunto dos organismos multilaterais de financiamento. O BM tornou-se o guardião dos interesses dos grandes credores internacionais, responsável por assegurar o pagamento da dívida externa e por empreender a reestruturação e abertura dessas economias, impondo uma série de condicionalidades para a concessão de novos empréstimos.

Com esse novo papel, o Banco reforçou a sua capacidade de impor políticas, dado que, sem seu aval e do FMI, todas as fontes de crédito internacional são fechadas, o que torna muito difícil a resistência de governos eventualmente insatisfeitos com a nova ordem. Através disto, surgem os programas de ajuste estrutural, que passaram a ser geridos pelo BM a partir do início dos anos 80. O objetivo dos programas de ajuste é assegurar o pagamento da dívida e transformar a estrutura econômica dos países de forma a fazer desaparecer características julgadas indesejáveis e inconvenientes ao novo padrão de desenvolvimento (neoliberal).

Por meio das condicionalidades, o BM começou a programar um amplo conjunto de reformas estruturais nos países endividados. Essas reformas, que atendem às necessidades do capital internacional em rápido processo de globalização, foram batizadas de "Consenso de Washington". O Consenso de Washington era regido por cinco medidas que seriam capazes, de acordo com o Banco Mundial, de colocar os países no caminho do desenvolvimento sustentável permitindo o retorno da estabilidade econômica, mesmo que aumentasse a pobreza.

Muitas vezes não existia consenso sobre a condicionalidade imposta pelos doadores e instituições, quer por motivos políticos (por exemplo, a presença da China na África, em particular no Sudão), quer por simples de-

guia prático dos mercados e instituições financeiras. Rio de Janeiro: Jorge Zahar, 2000. 
magogia (caso do presidente Chávez ao preconizar que o Banco do Sul não tenha condicionalidade, o que o levaria fatalmente à insolvência). Existem, pois, doadores que se opõem terminantemente a ela. Por outro lado, existe uma tendência, entre os doadores, a acrescentar ao elenco das condições exigidas aos países em desenvolvimento um número crescente de requisitos (por exemplo, cláusulas trabalhistas e ambientais em acordos de livre comércio) que, se satisfazem a moralidade doméstica entre os doadores, pouco ou nada têm a ver com a dos países assistidos, e muitas vezes neutralizam a efetividade de tal assistência. ${ }^{92}$

Cabe aqui uma observação: o total da cooperação não militar, de quaisquer fontes, concedida pelos países doadores do G- $8^{93}$, a título de ajuda oficial ao desenvolvimento (ODA), é liminarmente eclipsado pelo montante dos subsídios que esses países outorgam à sua produção agrícola, em detrimento das exportações das economias emergentes. É este o problema central das negociações da Rodada Doha da OMC, batizada de "Rodada do Desenvolvimento", mas esse objetivo há muito foi esquecido. Após a reunião do G-8 em Heiligendamm, em julho de 2007, a ministra alemã da Cooperação Econômica e do Desenvolvimento, Heidemrie Wieczorek-Zeul, declarou ser "uma preocupação central dos países industriais a abertura dos seus mercados aos produtos de países em desenvolvimento, e a redução dos seus subsídios à exportação, porque o que os países em desenvolvimento querem não são esmolas, mas uma oportunidade justa nos mercados" ${ }^{\prime 4}$. Infelizmente tão nobres desejos não se refletiram na Rodada de Doha; até agora não tem sido o caso.

A globalização está representada no plano ideológico pelo pensamento liberal ${ }^{95}$. Este ganha força a partir do final dos anos 1980, sendo que para os países em desenvolvimento é implementada uma nova concepção de política caracterizada pela imposição de um conjun-

92 LANDAU, Georges D. O Brasil e a cooperação internacional para o desenvolvimento. Revista de Economia \& Relações Internacionais, São Paulo, v. 6, n. 12, p. 103-116, jan. 2008.

93 Sete países mais industrializados do mundo: Alemanha, EUA, Canadá, França, Itália, Reino Unido e Japão, mais a Rússia.

94 IFPRI Forum interviews Achim Steiner on the environmental crisis facing the world and the solutions to that crisis. Disponível em: <http://www.unep.org/PDF/susdev ipiforum.pdf $>$. Acesso em: 25 maio 2016.

95 MARTINS, Carlos Estevam. Da globalização da economia à falência da democracia. Economia e Sociedade, Campinas, v. 6, p. 1-23, jun. 1996. to de medidas pelos organismos internacionais (BIRD e FMI) destinadas a englobar aquelas economias num novo panorama externo, em que predominam os ideários da globalização e da integração aos mercados financeiros internacionais. Dentre tais medidas, são advogadas as aberturas comerciais, a liberalização dos mercados financeiros, a desregulamentação do mercado de trabalho, as privatizações, e a redução do papel do Estado, com o corte de gastos públicos e o abandono das políticas sociais.

As políticas de ajuste neoliberais aplicadas na América Latina, na África e na Ásia foram traduzidas por um modelo criado pelo Banco Mundial, pelo Fundo Monetário Internacional (FMI) e pelo governo dos Estados Unidos: o chamado Consenso de Washington. O enfoque proposto pelo Consenso de Washington, chamado de ajuste estrutural, pretendia desencadear as mudanças que os países ricos julgavam "necessárias" para a estabilização dos países periféricos através da aplicação de um receituário de políticas liberalizantes, privatizantes e de mercado. Há que se ressaltar que as políticas gestadas pelo Consenso faziam parte de um movimento de ajuste no sistema mundial dentro do contexto da globalização financeira e produtiva. Em síntese, trata-se de políticas econômicas de estabilização acompanhadas de reformas estruturais liberalizantes ${ }^{96}$.

Robert $\mathrm{Cox}^{97}$ foi pioneiro, ao adaptar os constructos das análises gramscianas às relações internacionais, associando o conceito de hegemonia a uma concepção de poder. Assim, a hegemonia seria criada pela relação entre coerção e consenso, por meio dos “aparelhos privados de hegemonia”. O consenso é visto do mesmo modo que um processo construído pela articulação, fortalecimento ou descrédito das instituições de uma sociedade civil, tanto na esfera nacional, quanto nas relações internacionais. Perspectiva que também pode ser utilizada em subespaços regionais. $\mathrm{O}$ que em Gramsci é descrito como aparelhos privados de hegemonia, ou seja, organizações que não pertencem à esfera do Estado, para Robert Cox, ultrapassam as fronteiras do Estado-Nação para constituir as condições de conformação de uma sociedade civil global, mediante as diferentes instituições e organizações internacionais que

96 SOARES, Laura Tavares Ribeiro. Ajuste neoliberal e desajuste social na América Latina. Rio de Janeiro: UFRJ, 1999.

97 COX, Robert W.; SINCLAIR, Timothy J. Approaches to world order. Cambridge: Cambridge University Press, 1996. (Cambridge Studies in International Relations). 
atuam em diversos espaços nacionais, principalmente, por meio da cooperação internacional.

Cox se refere a forma consensual que o poder adquire na constituição de uma ordem mundial, podendo assim ser aceita pelas partes dominadas. Uma determinada classe social exerce a hegemonia quando transcende seus interesses econômicos particulares e é capaz de conectar diversas aspirações, interesses e identidades formando um bloco histórico. Os intelectuais têm um papel fundamental neste processo, desenvolvendo e sustentando imagens mentais, tecnologias e organizações que vinculam os membros de uma classe e de um bloco histórico na formação de uma identidade comum ${ }^{98}$. As reformas estruturais preconizadas pelo Consenso de Washington assumiram, no final dos anos 1980, uma convergência forçada e ganharam força de doutrina constituída, sendo aceita por vários países em desenvolvimento. Tais países, diante dos desequilíbrios de balanço de pagamentos, desajuste das contas públicas e altas taxas de inflação, recebiam das instituições internacionais um receituário de política econômica, cuja execução condicionava os empréstimos e financiamentos a serem concedidos. As medidas propostas pelo Consenso de Washington tiveram maior sucesso no que tange à estabilização inflacionária. No entanto, para atingir a estabilidade de preços, tais medidas acarretaram, nos diversos países, uma série de efeitos negativos.

Os neoliberais acusam os compromissos assumidos pelo Welfare State nos anos 1960 como a principal causa da desaceleração econômica mundial, devido à queda da lucratividade e da competitividade decorrente do aumento dos encargos fiscais e dos direitos sociais consagrados pelo Estado de bem estar social ${ }^{99}$. O argumento é de que a retomada do crescimento exigiria um aumento dos investimentos e da lucratividade incompatíveis com os níveis salariais e com a carga fiscal requerida pelos sistemas de proteção social obtidos pelos trabalhadores. Portanto, a solução da crise deveria passar pela desregulamentação dos mercados, flexibilização do mercado de trabalho e desestruturação do Estado de bem estar social ${ }^{100}$

98 HERZ, Mônica; HOFFMAN, Andrea. Organizações internacionais: histórias e práticas. Rio de Janeiro: Campus, 2004.

99 FIORI, José Luís. Condenados da terra. Folha de São Paulo, Caderno Mais!, São Paulo, abr. 1996.

100 MARQUES, Rosa Maria. Notas sobre o avanço do neoliberalismo no campo da proteção social. In: ENCONTRO DE
Há que se fazer uma revisão desse diagnóstico da crise mundial e dos resultados gerados pela aplicação das políticas neoliberais para se compreender por que a redução das cargas fiscais não incentivou o investimento e o crescimento econômico, e por que o gasto público tem aumentado, apesar da queda significativa dos gastos sociais. Em outras palavras, a crise fiscal do Estado está mais relacionada a acontecimentos no âmbito da economia mundial do que ao excesso de demandas dos trabalhadores. Tais acontecimentos alteraram radicalmente a face do capitalismo, deteriorando a base tributária, multiplicando a dívida pública e submetendo a liberdade da política econômica e social aos objetivos dos mercados financeiros ${ }^{101}$.

A crise fiscal do Estado encontra-se relacionada a três ordens de razões ${ }^{102}$. A primeira razão seria decorrente de fatores de caráter estrutural, dada a crise da previdência social ligada às mudanças na estrutura demográfica e do emprego, uma vez que a força de trabalho regularmente empregada estaria se restringindo enquanto o emprego informal estaria aumentando, tornando as contribuições dos empregados e empresas empregadoras insuficientes para sustentar os seguros sociais e as pensões da população inativa (velhos, jovens e mulheres).

A segunda razão está ligada ao processo de reestruturação produtiva e internacionalização acelerada, que contribui para a deterioração dos mecanismos de financiamento do Estado, na medida em que tais transformações desterritorializam a renda e o produto, dificultando sua mensuração e tributação, mas não desterritorializam os gastos públicos sociais e de produção de infraestrutura, que continuam a cargo do Estado. Além disso, contribui para este processo a informalidade de pequenas empresas na indústria e no setor de serviços, que sonegam impostos, e, portanto, solapa a base de arrecadação tributária do governo.

Por fim, a terceira razão, vista pelo lado do gasto corrente, encontra-se associada à lógica das políticas de ajuste impostas. Tal razão destaca-se por seu grande impacto nos países periféricos. Trata-se do peso crescente dos serviços financeiros da dívida pública, advindo da

ECONOMIA POLÍTICA, 3., 1998, Niterói. Anais... Niterói: Unesp, 1998. v. 2. p. 1143-1151.

101 FIORI, José Luís. Condenados da terra. Folha de São Paulo, Caderno Mais!, São Paulo, abr. 1996.

102 TAVARES, Maria da C. Ajuste e reestruturação nos países centrais: a modernização conservadora. Economia e Sociedade, Campinas, n. 1, p. 21-57, ago. 1992. 
manutenção de taxa de juros elevadas. Para análise desta razão, faz-se necessário comentar brevemente os resultados das políticas de ajuste neoliberais.

O modelo de ajuste neoliberal aplicado nos países em desenvolvimento, em suma, se reduz à implantação de políticas macroeconômicas que têm por objetivo restabelecer o equilíbrio dos balanços de pagamentos e controlar a inflação através de medidas recessivas. No entanto, tais políticas apresentaram efeitos negativos em termos de crescimento econômico e melhoria do padrão de vida da população. A aplicação de políticas monetárias restritivas para conter a inflação provocou elevação das taxas de juros e a redução dos investimentos no setor produtivo, causando queda do nível de atividade econômica e de emprego. Os juros altos também contribuíram para a elevação das dívidas externa e interna, deteriorando ainda mais as contas públicas e resultando em menores aportes de recursos para os setores sociais na tentativa de equilibrar as finanças do Estado.

A abertura comercial e a integração ao mercado internacional, em vez de tornar as empresas mais eficientes e competitivas, e propiciar a modernização da estrutura produtiva prevista pela tese neoliberal, acarretaram desintegração das indústrias nacionais, desnacionalização produtiva, quebra de empresas e aumento do desemprego. $\mathrm{Na}$ realidade, foi ilusão pensar no poder transformador em termos de modernização e competitividade que a política neoliberal poderia trazer aos países periféricos, uma vez que estas economias contaram com a forte participação do Estado para alavancar seus processos de industrialização ${ }^{103}$. Sem políticas setoriais, sobretudo industrial, induzidas pelo Estado, torna-se difícil a modernização produtiva e o que se observa é a ampliação do desemprego e o aumento da concentração de renda. Por outro lado, a debilidade a que as políticas de ajuste conduziram o Estado impede sua ação planejadora para o desenvolvimento ${ }^{104}$.

Torna-se necessário repensar de forma crítica os resultados das políticas neoliberais, pois embora a inflação tenha sido controlada, a adoção à risca do receituário neoliberal tem gerado elevados níveis de desemprego e a dívida pública se mantém crescente em função das altas

103 TAVARES, Maria da C. Ajuste e reestruturação nos países centrais: a modernização conservadora. Economia e Sociedade, Campinas, n. 1, p. 21-57, ago. 1992. taxas de juros praticadas. Sem uma reavaliação dessas políticas, os cortes dos gastos públicos e o aumento do número de desempregados e excluídos socialmente permanecerão, sem que se consiga o desejado equilíbrio fiscal, pois mesmo com o esmagamento das políticas sociais, o déficit público não consegue ser reduzido, já que são cada vez maiores os componentes financeiros das dívidas.

Verifica-se que as medidas de ajuste neoliberais têm impactos perversos sobre as políticas sociais, uma vez que tais medidas aumentam as demandas sociais devido ao alto desemprego e à deterioração das condições de vida, ao mesmo tempo em que restringem a oferta de bens e serviços sociais em função dos cortes dos gastos públicos pela exigência de equilíbrio fiscal. Assim, nas palavras de Fiori ${ }^{105}$, as restrições neoliberais contra o peso do Estado são de um "cinismo aterrador", pois a real crise fiscal do Estado é, em grande parte, originada das próprias políticas de ajuste, que, por um lado, aumentam as obrigações do Estado, ao ampliar as necessidades da sociedade de maiores gastos na área social, mas, por outro, elevam o gasto financeiro e restringe o crescimento, o que reduz a capacidade do Estado de prover maiores recursos sociais.

Uma das mais árduas críticas de Chossudovsky às políticas de ajuste diz respeito ao seu efeito negativo no processo de desenvolvimento econômico nacional endógeno dirigido por políticos internacionais. ${ }^{106}$. As medidas austeras determinadas pelas instituições financeiras alteram o quadro político-econômico do Estado em que é aplicada; a produção nacional, especialmente de commodities, é direcionada para o mercado mundial, o que torna os seus preços mais baixos em virtude do excesso de oferta e reduz o valor da hora-trabalho dos assalariados.

O Banco Mundial e o FMI reconhecem os insucessos decorrentes das políticas de ajuste estrutural. Declaram, porém, que a dor sofrida em curto prazo (custos sociais) resultaria em benefícios a longo prazo (estabilização macroeconômica). O Fundo reconhece o impacto social do seu ajuste, afirmando, porém, que não assume toda a responsabilidade pelos seus eventuais insucessos. Insiste, ainda, que o resulta geral em um longo período tende a ser positivo, mesmo havendo um custo inicial. $\mathrm{O}$

105 FIORI, José Luís. Condenados da terra. Folha de São Paulo, Caderno Mais!, São Paulo, abr. 1996.

106 CHOSSUDOVSKY, Michel. A globalização da pobreza: impacto das reformas do FMI e do Banco Mundial. Trad. Marylene Pinto Michael. São Paulo: Moderna, 1999. 
problema é que a dor tem se mostrado infindável e os remédios configuram-se como meros paliativos.

A implementação dessa espécie de ajuste não atingiu a estabilidade econômica idealizada pelos seus proponentes. Vários países empenharam-se para cumprir as metas do ajuste recessivo, encontrando-se, entretanto, em maiores dificuldades ${ }^{107}$. O maior prejudicado nesse sentido foi o setor público, pois fora obrigado a cortar gastos essenciais com drásticas repercussões no âmbito social. Em contrapartida, aumentou a carga tributária, com vistas ao aumento do superávit primário, sufocando alguns setores produtivos e prejudicando investimentos em infra-estrutura. Os juros altos limitam fortemente o crédito interno. A promoção de privatizações intensificou-se na medida em que se tentava ajustar as contas públicas. $\mathrm{O}$ setor privado, por sua vez, adotou a política de redução de salários, diminuição de encargos e emprego informal.

Daí o Direito Internacional, em suas diversas ramificações, tem por fundamento a cooperação internacional em direção à conquista de objetivos comuns. As instituições financeiras multilaterais não estão apenas autorizadas, mas legalmente requisitadas a perseguir esses objetivos nos seus programas de empréstimo. Essas instituições não possuem uma faculdade, mas sim uma obrigação internacional de, ao realizar empréstimos, levar em consideração fatores não econômicos ${ }^{108}$ porquanto um progresso efetivo das estratégias de combate à pobreza depende de uma ampla coalizão entre os indivíduos, grupos da sociedade civil, organizações não governamentais, governos, agências de desenvolvimento e organizações internacionais. Segundo o direito internacional, convencional ou costumeiro ${ }^{109}$, existem principios e regras juridicos basicos que dizem respeito à proteçao internacional dos direitos humanos que se estendem a todos os sujeitos de direito internacional.

SOARES, Laura Tavares Ribeiro. Ajuste neoliberal e desajuste social na América Latina. Rio de Janeiro: UFRJ, 1999.

108 MELLO, Celso Divivier de Albuquerque. Curso de direito internacional público. 12. ed. Rio de Janeiro: Renovar, 2000. v. 1.

109 O direito convencional é o direito escrito cujas regras se encontram nas convençoes internacionais, tal como o Pacto Internacional sobre os direitos economicos, sociais e culturais (PIDESC). O direito costumeiro é o direito nao escrito mas que coage, como a interdiçao dos crimes contra a humanidade, dos crimes contra a agressao, os direitos dos povos sobre seus recursos naturais etc [...]. BALERA, Wagner; SILVEIRA, Vladimir Oliveira da (Coord.). Comentários ao Pacto Internacional dos Direitos Econômicos, Sociais e Culturais. Curitiba: Clássica, 2013.
Tanto o FMI, o BM quanto a OMC sao organizaçoes internacionais ${ }^{110}$. E como tal, eles possuem uma personalidade juridical internacional ${ }^{111}$, tem seus próprios orgãos ${ }^{112}$, são dotados de competencias pelo tratado ou acordo de base (competencia de atribuição) ${ }^{113}$, sobretudo, como organizaçoes internacionais, eles tem direitos e obrigaçoes. Em regra geral, nenhuma organizaçao internacional que pretende agir como sujeito de direito internacional, que entende exercer suas competencias e que pretende ter uma personalidade jurídica internacional não pode seriamente argumentar que ela està imune de cumprir obrigaçoes internacionais, especialmente regras de proteção dos direitos humanos. Como sujeito de direito internacional, toda organização internacional està submetida ao direito internacional, incluindo a submissão às regras de proteção aos direitos humanos.

As instituições internacionais tem então a obrigação de criar as condições necessàrias para o cumprimento de todos os direitos humanos, o respeito, a proteção e a promoção destes direitos. Ora os programas de ajuste estrutural não cumprem esta missão. Hoje rebatisados de " estratégias de luta contra a pobreza ", elas postulam que o simples crescimento economico trarà o desenvolvimento ; o que foi desmentido pelos relatorios anuais do Programa das Naçoes Unidas para o Desenvolvimento (PNUD). O crescimento economico, tal como proposto pelas instituiçoes financeiras internacionais beneficia sobretudo as camadas mais privilegiadas da sociedade $\mathrm{e}$ aumentam sempre a dependencia dos paises do Terceiro Mundo $^{114}$. A mais, o crescimento econômico atual está fundamentalmente incompatível com a preservação do direito ao desenvolvimento, sobretudo dos direitos humanos.

Eric Toussaint ${ }^{115}$ explica que é possivel responsabilizar e ajuizar uma ação contra o BM. Uma tese muito

10 RIDRUEJO, J. A. Pastor. Curso de Derecho Internacional Público y Organizaciones Internacionales. 6. ed. Madrid: Tecnos, 1996. p. 803.

11 COUR INTERNATIONALE DE JUSTICE. Réparation des dommages subis au service des Nations Unies, 1949.

112 VERHOEVEN, J. Droit international public: précis de la Faculté de Droit de l'UCL. Bruxelles: Larcier, 2000. p. 205.

113 COMBACAU, Jean; SUR, Serge. Droit international public: Montchrestien. 2. ed. Paris: LGDJ, 1995.

114 ANGULO SÁNCHEZ, Nicolás. El derecho humano al desarollo frente a la mundialización del mercado: conceptos, contenido, objetivos y sujetos. Madrid: IEPALA, 2005.

115 TOUSSAINT, Eric. Banque Mondiale: le coup d'état permanent: l'agenda caché du consensus de Washington. Paris: Syllepse; Genève: Cetim; Liège: CADTM, 2006. 
espalhada pretende que o BM beneficia de uma imunidade como agencia especializada das Nações Unidas, conforme a convenção da ONU de 1947 que atribui imunidade às suas agências especializadas. Cabe salientar que na oportunidade o BM anexou um documento, onde declarou a possibilidade de ser ajuizada uma ação judicial contra ele. O BM renunciou à sua imunidade para convencer os banqueiros a lhe emprestar dinheiro. Nenhum banqueiro aceitaria lhe emprestar dinheiro ou compraria seus títulos se este beneficiasse de uma imunidade total.

Entao està claro : os estatutos do BM permitem às entidades, aos individuos ajuizarem ações judiciais contra ele. Mas os Estados membros do BM ou as entidades que representem os interesses dos Estados membros não podem ajuizar ações contra o banco, mas nós como cidadãos podemos. Aqueles que sofrerem pela intervençao do $\mathrm{BM}$ podem se constituir em associação para defender os interesses das vitimas. [...] Estou certo que cedo ou tarde $\mathrm{o}$ BM serà processado.

Os principais textos das Nações Unidas dizem respeito tanto aos direitos individuais, aos direitos coletivos, ao direito ao desenvolvimento quanto ao direito à soberania politica e econômica dos Estados. De fato, o BM, mas também o FMI, a OMC, as sociedades transnacionais, nunca aceitaram se submeter a estes direitos. Estas instituiçoes contaram com uma terrível impunidade até agora apesar de alguns avanços interessantes, tal como o Tribunal Penal Internacional (TPI) ; mesmo que o direito atual esteja longe de ser perfeito. Uma sèrie de instrumentos e de jurisdições em matéria de crimes contra os direitos humanos individuais e de crimes contra a humanidade existe ; mas outros crimes que fazem um grande número de vitimas ao redor do mundo, os crimes economicos, não fazem objeto de nenhuma jurisdição internacional, de nehuma convenção, de nenhuma definição internacioal até hoje $\mathrm{e}^{116}$.

Conforme a máxima jurídica, a todo direito corresponde um dever, tendo em vista a atuação do Banco Mundial nas políticas dos países e a imposição de condicionantes para os empréstimos, julgamos, se não for responsável, pelo menos corresponsável pelo fracasso das politicas aplicadas pelos países, com base nas suas orientações. Inclusive temos um embasamento legal e doutrinário, para sugerir isso, pois conforme foi mencionado

116 TOUSSAINT, Eric. Banque Mondiale: le coup d'état permanent: l'agenda caché du consensus de Washington. Paris: Syllepse; Genève: Cetim; Liège: CADTM, 2006. acima, com a entrada em vigor do Painel de Inspeção, em 1994, proporcionou-se, pela primeira vez, um veículo para cidadãos, e especialmente, pessoas pobres, acessarem diretamente a mais alta instância administrativa do Banco Mundial - o Conselho de Diretores Executivos e buscar reparação para o que pode ser entendido como consequências operacionais prejudiciais do Banco Mundial. Esta responsabilidade ou corresponsabilidade, seria um requisito muito importante para que os projetos de desenvolvimento possam ter êxito. Esta responsabilidade deveria ser analisada sob o enfoque de responsabilidade internacional.

A responsabilidade política pela cooperação está articulada com o estabelecimento de uma relação perfeita entre as decisões e responsabilização política com as suas imposições de racionalidade, eficiência e eficácia, mas evitando qualquer tipo de centralização asfixiadora. Desta forma, verificam-se três objetivos fundamentais para alcançar esta conciliação: o primeiro consiste na elaboração de mecanismos mais adequados para o orçamento e execução da ajuda oficial ao desenvolvimento (ODA); o segundo reside no desenvolvimento de mecanismos de coordenação internacional a nível político; e o terceiro consiste na valorização e coordenação das iniciativas da sociedade civil, nas suas diferentes revelações, em proveito de uma abordagem comum.

Com base nas regras contemporâneas do direito internacional, as politicas aplicadas pelas instituições financeiras internacionais são atos ilícitos. $\mathrm{O}$ artigo $3^{\circ}$ do projeto da comissão de direito internacional da ONU sobre a responsabilidade internacional dos Estados relembra a este respeito: “ Há fato internacionalmente ilícito quando:

a) um comportamento que consiste em uma ação ou omissão é atribuído, segundo o direito internacional ao Estado; e

b) este comportamento constitui uma violação de uma obrigação internacional”

Sem nenhuma dúvida, o regime da responsabilidade internacional é aplicável ás instituições financeiras internacionais. Estas são responsáveis por violações massivas e sistemáticas do direito internacional como consequência das suas politicas no contexto dos programas de ajustes estruturais. Ao mesmo tempo, o regime de responsabilidade internacional diz respeito à violação das regras do direito penal internacional ou das normas ditas imperativas. 


\section{Conclusão}

Tratando de atos ilícitos, a obrigação de reparação é uma regra profundamente enraizada no direito internacional, à qual as instituições financeiras internacionais não podem se eximir invocando seu direito interno. Tendo em vista os interesses e a importância dos direitos em jogo, visto a amplitude das violações sistemáticas em grande escala dos direitos humanos, devido à aplicação de politicas neoliberais, seus responsáveis e as instituições podem ser processados para que as vítimas obtêm uma reparação e indenização pelos prejuízos, incluindo as violações dos direitos econômicos, sociais e culturais durante mais de vinte anos.

As instituições financeiras internacionais e seus dirigentes são penalmente responsáveis pelas graves violações das normas imperativas, especialmente sua cumplicidade com algumas ditaduras pela ajuda direta do $\mathrm{BM}$ a estes regimes criminais. A mais tendo em vista à violação, pelas instituições financeiras internacionais, de regras de proteção aos direitos humanos, tem aí um ato internacionalmente ilícito e elas são internacionalmente responsáveis. Consequentemente, elas têm o dever de reparar os danos inclusive a restituição integral dos bens espoliados por alguns governos. As violações aos direitos humanos são expressamente proibidas pelo direito internacional.

Os cidadãos cujos direitos humanos foram violados pela ação das instituições financeiras internacionais, como vítimas, deveriam procurar os tribunais locais e outros tribunais competentes para demandarem, por um lado as reparações e indenizações devidas pelo BM, e por outro lado, iniciarem processos penais contra esta mesma instituição e seus responsáveis por participação às violações graves das normas de direito internacional.

\section{Referências}

ANGULO SÁNCHEZ, Nicolás. El derecho humano al desarollo frente a la mundialización del mercado: conceptos, contenido, objetivos y sujetos. Madrid: IEPALA, 2005.

ARRETCHE, M. T. S. Emergência e desenvolvimento do welfare state: teorias explicativas. Boletim Informativo $e$ Bibliográfico de Ciências Sociais, Rio de Janeiro, n. 39, p. 1-124, 1995.

AZEVEDO, Plauto Faraco de. Justiça distributiva e aplicação do Direito. Porto Alegre: Sérgio Fabris, 1983.
BANCO MUNDIAL. Sobre o Banco Mundial. Disponível em: <http://www.bancomundial.org.br>. Acesso em: 14 set. 2013.

BARACHO JÚNIOR, José Alfredo de Oliveira. Responsabilidade civil por dano ao meio ambiente. Belo Horizonte: Del Rey, 2000.

BARACHO JÚNIOR, José Alfredo de Oliveira. Responsabilidade civil por dano ao meio ambiente. Belo Horizonte: Del Rey, 2000.

BECK, Ulrich. Risk society: towards a new modernity. London: Sage, 1992.

BIRD, Graham. International financial policy and economic development. 2. ed. London: Macmillan, 1989.

BRANDÃO, Carlos. Território e desenvolvimento: as múltiplas escalas entre o local e o global. Campinas: Unicamp, 2007.

CARVALHO, Délton Winter de. Dano ambiental futuro: a responsabilização civil pelo risco ambiental. Rio de Janeiro: Forense Universitária, 2008.

CASTRO, Fabiana Maria Martins Gomes de. Sociedade de risco e o futuro consumidor. Revista de Direito do Consumidor, São Paulo, v. 11, n. 44, p. 122-140, out./dez. 2002.

CASTRO, Robinson Gonçalves de. Relações econômicas internacionais. 2. ed. Brasília: Vestcon, 2000.

CAVALIERI FILHO, Sergio. Programa de responsabilidade civil. 8. ed. São Paulo: Atlas, 2008.

CHOSSUDOVSKY, Michel. A globalização da pobreza: impacto das reformas do FMI e do Banco Mundial. Trad. Marylene Pinto Michael. São Paulo: Moderna, 1999.

COMBACAU, Jean; SUR, Serge. Droit international public: Montchrestien. 2. ed. Paris: LGDJ, 1995.

COUR INTERNATIONALE DE JUSTICE. Réparation des dommages subis au service des Nations Unies, 1949.

COX, Robert W.; SINCLAIR, Timothy J. Approaches to world order. Cambridge: Cambridge University Press, 1996. (Cambridge Studies in International Relations).

CRETELLA JUNIOR, José. O Estado e a obrigação de indenizar. 2. ed. Rio de Janeiro: Forense, 2002.

DEMAJOROVIC, Jacques. Sociedade de risco e responsabilidade socioambiental: perspectivas para a educação corporativa. São Paulo: SENAC, 2003. 
DERANI, Cristiane. Direito ambiental econômico. 5. ed. São Paulo: Max Limonad, 2001.

DIEZ-PICAZO, Luis. Experiencias jurídicas y teoría del derecho. 3. ed. Barcelona: Ariel, 1999.

FIORI, José Luís. Condenados da terra. Folha de São Paulo, Caderno Mais!, São Paulo, abr. 1996.

FIORI, José Luís. Os moedeiros falsos. Petrópolis: Vozes, 1997.

FOSCHETE, Mozart. Relações econômicas internacionais. 2. ed. São Paulo: Aduaneira, 2001.

GIORGI, Raffaele de. Direito, democracia e risco: vínculos com o futuro. Porto Alegre: Safe, 1993.

HAQUE, M. Shamsul. Restructuring development theories and policies: a critical study. Albany: State University of New York Press, 1999.

HERZ, Mônica; HOFFMAN, Andrea. Organizações internacionais: histórias e práticas. Rio de Janeiro: Campus, 2004.

KRAYCHETE, Elsa Sousa. O Banco Mundial e o desenvolvimento das microfinanças em países da periferia capitalista. 2005. 222 f. Tese (Doutorado) - Programa de Pós-Graduação em Administração, Universidade Federal da Bahia, Salvador, 2005.

KURZ, Robert. O futuro é diferente: uma visão da sociedade do século 21. In: OSZLAK, Oscar. Sociedade e Estado superando fronteiras. São Paulo: Fundap, 1998. p. 15-34.

LANDAU, Georges D. O Brasil e a cooperação internacional para o desenvolvimento. Revista de Economia \& Relações Internacionais, São Paulo, v. 6, n. 12, p. 103-116, jan. 2008.

LEVY, Emmanuel. Responsabilité et contrat. Revue critique de Legislation et Jurisprudence, Paris, v. 28, p. 361-399, trimestrielle, 1998.

LIMA, Alvino. Culpa e risco. 2. ed. São Paulo: RT, 1998.

LUHMANN, Niklas. Sociologia do direito. Rio de Janeiro: Tempo Brasileiro, 1983. v. 1.

MAIA, M. E. R. Cenários para o sistema financeiro internacional. 1999. Dissertação (Mestrado) - Instituto de Ciência Política e Relações Internacionais, Universidade de Brasília, Brasília, 1999.

MARQUES, Rosa Maria. Notas sobre o avanço do neoliberalismo no campo da proteção social. In: ENCONTRO DE ECONOMIA POLÍTICA, 3., 1998, Niterói. Anais... Niterói: Unesp, 1998. v. 2. p. 1143-1151.
MARTINS, Carlos Estevam. Da globalização da economia à falência da democracia. Economia e Sociedade, Campinas, v. 6, p. 1-23, jun. 1996.

MATTOZI, Ignácio de Cuevillas. La reación de causalidad em la órbita del derecho de daños. Valencia: Tirant lo Blanch, 2000.

MELLO, Celso Divivier de Albuquerque. Curso de direito internacional público. 12. ed. Rio de Janeiro: Renovar, 2000. v. 1.

MILLARÉ, Édis. Direito do ambiente: doutrina, prática, jurisprudência, glossário. 2. ed. São Paulo: RT, 2001.

MORAES, Maria Celina Bodin de. O principio da solidariedade. In: PEIXINHO, Manoel Messias (Org.). Os princípios da Constituição de 1988. Rio de Janeiro: Lúmen Júris, 2001. p. 167-190.

MORIN, Edgar. Para onde vai o mundo?. Tradução de Francisco Moras. 2. ed. Petrópolis: Vozes, 2010.

MULHOLLAND, Caitlin Sampaio. A responsabilidade civil por presunção de causalidade. Rio de Janeiro: GZ, 2009.

PEREIRA, Caio Mário da Silva. Responsabilidade civil. 3. ed. Rio de Janeiro: Forense,1992.

PEREIRA, João Márcio Mendes. O Banco Mundial como ator político, intelectual e financeiro. Rio de Janeiro: Civilização Brasileira, 2010.

PORTELA, Paulo Henrique Gonçalves. Direito internacional público e privado: incluindo noções de direitos humanos e de direito comunitário. 2. ed. rev. ampl. e atual. São Paulo: JusPodivm, 2010.

RIBEIRO FILHO, Geraldo Browne. O Banco Mundial e as cidades: construindo instituições na periferia: o caso do PRODUR, Bahia. 2006. 243 f. Tese (Doutorado) - Programa de Pós-Graduação em Planejamento Urbano e Regional, Universidade Federal do Rio de Janeiro, Rio de Janeiro, 2006.

RIBEIRO, Patrícia. A responsabilidade civil objetiva do direito de danos. Rio de Janeiro: Forense, 2004.

RIDRUEJO, J. A. Pastor. Curso de derecho internacional público y organizaciones internacionales. 6. ed. Madrid: Tecnos, 1996.

RIDRUEJO, José Antonio Pastor. Le droit international à la veille du vingt et unième siècle: normes, faits et valeurs: cours général de droit international public. Boston: The Hague Academy of International Law, 1998. t. 274.

ROBERTS, Richard. Por dentro das finanças internacionais: guia prático dos mercados e instituições financeiras. Rio de Janeiro: Jorge Zahar, 2000. 
SALVATORE, Dominick. Economia internacional. 6. ed. Rio de Janeiro: LTC , 2000.

SAMPAIO, Rogério Marrone de Castro. Direito civil: responsabilidade civil. 3. ed. São Paulo: Atlas, 2003.

SANTOS, Mauro Henrique Pereira dos. A responsabilidade civil objetiva na atividade bancária das instituições financeira. Âmbito Jurídico, Rio Grande, v. 8, n. 20, fev. 2005. Disponível em: <http://www.ambito-juridico.com. br/site/?n_link=revista_artigos_leitura\&artigo_id=831>. Acesso em: 11 out. 2013.

SÉGUIN, Elida. O direito ambiental: nossa casa planetária. Rio de Janeiro: Forense, 2000.

SOARES, Laura Tavares Ribeiro. Ajuste neoliberal e desajuste social na América Latina. Rio de Janeiro: UFRJ, 1999.

STEIGLEDER, Annelise Monteiro. Considerações sobre o nexo de causalidade na responsabilidade civil por dano ao meio ambiente. Revista de Direito Ambiental, São Paulo, ano 8, n. 32, p. 83-103, out./dez. 2003.

STOCO, Rui. Tratado de responsabilidade civil: responsabilidade civil e sua interpretação doutrinária e jurisprudencial. 5. ed. São Paulo: Revista dos Tribunais, 2001.

TAVARES, Maria da C. Ajuste e reestruturação nos países centrais: a modernização conservadora. Economia e Sociedade, Campinas, n. 1, p. 21-57, ago. 1992.
TOUSSAINT, Eric. Banque Mondiale: le coup d'état permanent: l'agenda caché du consensus de Washington. Paris: Syllepse; Genève: Cetim; Liège: CADTM, 2006.

VARELLA, Marcelo Dias. Direito internacional público. São Paulo: Saraiva, 2009.

VENOSA, Sílvio de Salvo. Direito civil: responsabilidade civil. 3. ed. São Paulo: Atlas, 2003. v. 4.

VERHOEVEN, J. Droit international public: précis de la Faculté de Droit de l'UCL. Bruxelles: Larcier, 2000.

VINEY, Geneviève; KOURILSKY, Patrick. Le príncipe de précaution. Paris: Odile Jacob, 1999.

WORLD BANK. IBRD Articles of Agreement, 2003. Disponível em: <http://siteresources.worldbank.org/BODINT/Resources/278027-1215526322295/IBRDArticlesOfAgreement_English.pdf>. Acesso em: 14 set. 2013.

WORLD BANK. How to File a Complaint. Disponível em: <http://www.cao-ombudsman.org/howwework/filecomplaint>. Acesso em: 14 mar. 2013.

WORLD BANK. World Bank lending instruments: resources for development impact (operations policy and strategy). Washington: World Bank, 2001.

Artigo produzido com o apoio da Fundação CAPES ${ }^{117}$ 